J Proteome Res. 2016 December 02; 15(12): 4436-4451. doi:10.1021/acs.jproteome.6b00521.

\title{
Determining the Mitochondrial Methyl Proteome in Saccharomyces cerevisiae using Heavy Methyl SILAC
}

\author{
Katelyn E. Caslavka Zempel§, Ajay A. Vashisht ${ }^{\dagger}$, William D. Barshop ${ }^{\dagger}$, James A. \\ Wohlschlegel ${ }^{\dagger}$, and Steven G. Clarke ${ }^{\S}{ }^{*}$ \\ $\S$ Department of Chemistry and Biochemistry and the Molecular Biology Institute, UCLA, Los \\ Angeles, California 90095, United States \\ † Department of Biological Chemistry and the David Geffen School of Medicine, UCLA, Los \\ Angeles, California 90095, United States
}

\begin{abstract}
Methylation is a common and abundant post-translational modification. High-throughput proteomic investigations have reported many methylation sites from complex mixtures of proteins. The lack of consistency between parallel studies, resulting from both false positives and missed identifications, suggests problems with both over-reporting and under-reporting methylation sites. However, isotope labeling can be used effectively to address the issue of false positives and fractionation of proteins can increase the probability of identifying methylation sites in lower abundance. Here, we have adapted heavy methyl SILAC to analyze fractions of the budding yeast Saccharomyces cerevisiae under respiratory conditions to allow for the production of mitochondria, an organelle whose proteins are often overlooked in larger methyl proteome studies. We have found 12 methylation sites on 11 mitochondrial proteins, as well as an additional 14 methylation sites on 9 proteins that are non-mitochondrial. Of these methylation sites, 20 sites have not been previously reported. This study represents the first characterization of the yeast mitochondrial methyl proteome and the second proteomic investigation of global mitochondrial methylation to date in any organism.
\end{abstract}

\section{Keywords}

heavy methyl SILAC; methylation; methyl proteome; mitochondria; MudPIT; yeast; protein lysine methylation; protein arginine methylation

\footnotetext{
*Corresponding Author Address: Department of Chemistry and Biochemistry and the Molecular Biology Institute, UCLA, 607 Charles E. Young Drive East, Los Angeles, California 90095, United States. Tel: 310 825-8754. Fax: 310 825-1968.

clarke@mbi.ucla.edu.

Supporting Information

The following files are available free of charge at ACS website: http://pubs.acs.org.

Raw mass spectrometry files are available for upload at MassIVE repository (accession number MSV000080107).

Author Contributions

The manuscript was written through contributions of all authors. All authors have given approval to the final version of the manuscript.

The authors declare no competing financial interest.
} 


\section{INTRODUCTION}

Often associated with the histone code, protein methylation is gaining recognition as a significant post-translational modification that can lead to enhanced function and regulation ${ }^{1}$. Much effort has been placed into identifying non-histone protein substrates of methyltransferases ${ }^{2-5}$, especially in the baker's yeast, Saccharomyces cerevisiae, which has one of the most fully characterized methyltransferasomes ${ }^{6-9}$. A third of $S$. cerevisiae genes are orthologous to human genes and half of the essential orthologous human genes exhibit functional complementarity in yeast ${ }^{10}$. Global methylation in yeast has been investigated through the use of high throughput proteomics ${ }^{11-15}$. Since these studies have been performed with yeast grown in D-glucose, conditions where production of mitochondrial proteins is suppressed, mitochondrial methylation remains largely uncharacterized. Much of what is known about human mitochondrial defects has come from yeast studies ${ }^{16}$. Therefore, understanding the methylation of yeast mitochondrial proteins may increase our understanding for other eukaryotes.

The majority of protein methylation occurs on lysine and arginine residues. Known substrates for protein arginine and lysine methyltransferases are generally localized in the nucleus and cytoplasm ${ }^{17-19}$ with significant methylation present in the cytoplasmic translational apparatus ${ }^{20}$, which contains some of the more abundant proteins in the cell. Hence, the majority of methylation sites being identified in large-scale protein modification studies via proteomics would be from these more abundant cellular compartments.

Mitochondrial proteins may be in much lower abundance than their nuclear and cytoplasmic counterparts $^{21}$, presenting a potential problem for proteomic studies of mitochondrial methylation.

Furthermore, less focus has been placed on the proteomic study of mitochondrial methylation. To date, there has only been one proteomic study of protein arginine methylation in the mitochondria, performed in Trypanosoma bruce ${ }^{22}$. Only two methylated mitochondrial proteins have been well characterized in $S$. cerevisiae. Cytochrome c is trimethylated on a lysine residue by $\mathrm{Ctm} 1$ prior to import ${ }^{23}$, a modification that has been implicated in import, stability, protein-protein interactions, and apoptosis ${ }^{24-28}$. The mitochondrial translation release factor (Mrf1) is methylated by Mtq1 on a conserved glutamine residue, which is substoichiometric yet required for translation ${ }^{29}$. However, there are four putative protein methyltransferases ${ }^{6-8}$ that are localized to the mitochondria but have unknown substrates: Rsm22 $2^{30}, \mathrm{Mtf1}^{31}, \mathrm{Oms} 1^{32}$, and Yk1162 $\mathrm{c}^{33}$. This suggests that more mitochondrial protein substrates for methylation have yet to be identified.

A bottom-up approach to identify global mitochondrial protein methylation is desirable due to post-import processing of mitochondrial proteins ${ }^{34}$ that complicates top-down methods. This approach is not without its drawbacks, especially when identifying methylation sites. There are two major issues with large-scale studies to detect methylation sites in proteins: a high false discovery rate and a low abundance of many methylated proteins ${ }^{35}$. Some of the artifactual methylation seen in large-scale studies that use $\Delta 14$ Da mass-shift based identification to detect methyl groups is due to sample preparation or processing for mass spectrometry, especially for samples prepared in methanol and ethanol ${ }^{36-38}$. Many amino 
acid substitutions can result in changes of 14,28 , and 42 Da, so relying on mass-shift alone could also incur misidentification of methylation on peptides ${ }^{39}$. Search algorithms can contribute to false positives due to the misidentification of modifications as well ${ }^{40}$. Additionally, methylation may be substoichiometric and/or on low abundance proteins, making the sites difficult to detect in the background of more abundant species ${ }^{41}$. To make matters worse, low precursor ion abundances can lead to poor fragmentation ${ }^{35}$. As a result, there is often little to no overlap between the results of various yeast proteomics studies ${ }^{12,14,15}$. Thus, some previously reported methyl identifications may be artifactual and many physiological methylation sites have likely escaped detection.

To overcome both of these problems, isotopic labeling coupled with analysis of purified subcellular fractions can be very useful. Heavy methyl stable isotope labeling by amino acids in cell culture (SILAC) can allow for unambiguous assignment of methylation to peptides $^{39}$. This has been used with much success in human proteomic studies of methylation $^{42-46}$, with improvements being made to the method ${ }^{47}$, but is less utilized in yeast $^{15,48}$. Recently, using heavy methyl SILAC in $S$. cerevisiae, Hart-Smith et al. ${ }^{49}$ found that large scale mass spectrometry identifications of methylation sites typically have high false discovery rates and emphasized the need for this type of methylpeptide validation. We have adapted heavy methyl SILAC for use with $S$. cerevisiae under respiratory conditions to allow for a full complement of mitochondria. Here, we report the identification of 26 methylation sites, likely to be on lysine and arginine residues, in 20 proteins across three protein fractions, including 20 novel sites. This study presents the first characterization of the mitochondrial methyl proteome in yeast. Coupled with the results from previous proteomic studies, our work suggests that we may have only identified a fraction of biologically relevant modifications.

\section{MATERIALS AND METHODS}

\section{Yeast Strains}

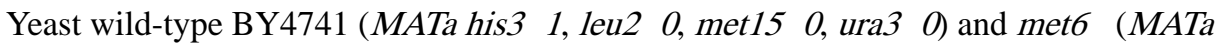

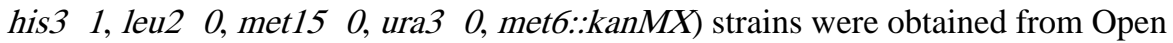
Biosystems (now GE Dharmacon).

\section{Heavy Methyl SILAC}

Cells were grown in $2 \mathrm{~L}$ of synthetic lactate media ${ }^{50}$ modified for heavy methyl SILAC. Instead of yeast extract, $1.75 \mathrm{~g} / \mathrm{L}$ yeast nitrogen base without amino acids or ammonium sulfate and $5 \mathrm{~g} / \mathrm{L}$ ammonium sulfate were used. For light cultures, $0.79 \mathrm{~g} / \mathrm{L}$ complete supplement mixture powder (CSM, MP Biomedicals) were added. For heavy cultures, CSM was omitted and the medium was supplemented with $0.75 \mathrm{~g} / \mathrm{L}$ methionine dropout amino acid mix (CSM-Met, MP Biomedicals) and $20 \mathrm{mg} / \mathrm{L}$ L-methionine (methyl-D $3,98 \%$ ) (Cambridge Isotope Laboratories, Inc.). Cells were grown in a shaker incubator at $30{ }^{\circ} \mathrm{C}$ at $250 \mathrm{rpm}$ to an optical density at $600 \mathrm{~nm}$ of about 3 and harvested by centrifugation at 5,000 $\times \mathrm{g}$ for 5 minutes. 


\section{Protein Fractionation}

Crude mitochondria were obtained as previously described ${ }^{50}$ from each of the $2 \mathrm{~L}$ heavy and light cultures described above. Mitochondria were lysed using 1.3\% Triton X-100 in 350 $\mathrm{mM}$ ammonium chloride, $20 \mathrm{mM}$ magnesium acetate, $1 \mathrm{mM}$ EDTA, $2 \mathrm{mM} \beta$ mercaptoethanol, $20 \mathrm{mM}$ Tris- $\mathrm{HCl}, \mathrm{pH}$ 7.5. The lysates (about $5 \mathrm{~mL}$ ) were cleared by centrifugation at $30,000 \times \mathrm{g}$ for $10 \mathrm{~min}$ at $4{ }^{\circ} \mathrm{C}^{51}$ and the protein concentration determined by Lowry assay ${ }^{52}$ after $10 \%$ trichloroacetic acid precipitation. For preparation of samples of crude mitochondria for mass spectrometry, equal amounts of protein from the light and heavy lysates were combined ( $500 \mu \mathrm{g}$ each for a total of $1 \mathrm{mg}$ of protein) and subjected to detergent removal and desalting using Pierce Polyacrylamide Spin Desalting Columns (7K MWCO) (Life Technologies). The de-salted preparation was then precipitated with trichloroacetic acid as described ${ }^{53}$. Combined heavy and light mitochondrial lysates were stored at $-20{ }^{\circ} \mathrm{C}$ until preparation for mass spectrometry analysis.

A fraction of mitochondrial ribosomal proteins was prepared from the crude mitochondrial lysates described above. Lysates $(4 \mathrm{~mL})$ were centrifuged on top of a sucrose cushion (1 M sucrose, $0.1 \mathrm{M}$ potassium chloride, $10 \mathrm{mM}$ magnesium chloride, $0.1 \mathrm{mM}$ EDTA, $1 \mathrm{mM}$ dithiothreitol, $2 \mathrm{mM}$ TES, $\mathrm{pH}$ 7.6) at $180,000 \times \mathrm{g}$ for $3 \mathrm{~h}^{54}$ at $4{ }^{\circ} \mathrm{C}$ with a Ti65 rotor (Beckman). The mitochondrial ribosomal proteins were acetic acid extracted as described previously ${ }^{55}$ and protein concentrations were determined. Equal amounts of protein (5-10 $\mu \mathrm{g}$ each for a total of 10-20 $\mu \mathrm{g}$ of protein) from the light and heavy fractions were combined. Extracted proteins were dried using vacuum centrifugation and stored at $-20{ }^{\circ} \mathrm{C}$ until preparation for mass spectrometry analysis.

A third fraction was prepared from the supernatant of the initial mitochondrial pelleting described above. This largely cytosolic fraction was centrifuged at $159,000 \times \mathrm{g}$ for $2 \mathrm{~h}$ at $4{ }^{\circ} \mathrm{C}$ with a Ti65 rotor (Beckman) to pellet ribosomes. The ribosomal proteins were acetic acid extracted ${ }^{55}$ and their protein concentration determined. Equal amounts of heavy and light protein (100 $\mu \mathrm{g}$ each for a total of $200 \mu \mathrm{g}$ of protein) were combined. Extracted proteins were dried in a vacuum centrifuge and stored at $-20{ }^{\circ} \mathrm{C}$ until preparation for mass spectrometry analysis.

Heavy methyl SILAC was performed in biological triplicate for cytoplasmic ribosomal proteins and mitochondria and biological duplicate for mitochondrial ribosomal proteins. Each biological replicate came from independently grown cultures.

\section{Protease Digestion}

Light- and heavy-labeled protein samples derived from purified cytoplasmic ribosome, mitochondria, or purified mitochondrial ribosomes were mixed in a 1:1 ratio. Purified samples were precipitated using trichloroacetic acid and then resuspended in digestion buffer (100 mM Tris, $\mathrm{pH} 8.5,8 \mathrm{M}$ urea). Reduction and alkylation were performed sequentially by incubating the samples in $5 \mathrm{mM}$ TCEP-HCl for 20 minutes at room temperature followed by $10 \mathrm{mM}$ iodoacetamide for 20 minutes at room temperature in the dark. The samples were then digested with Lys-C and trypsin proteases. First, Lys-C was added at an enzyme to substrate ratio of 1:100 and incubated for 4 hours at $37^{\circ} \mathrm{C}$. Following Lys-C digestion, the 
samples were diluted to $2 \mathrm{M}$ urea using $100 \mathrm{mM}$ Tris, $\mathrm{pH} 8.5, \mathrm{CaCl}_{2}$ was added to a final concentration of $1 \mathrm{mM}$ and trypsin was added at an enzyme to substrate ratio of 1:50 for 12 hours at $37{ }^{\circ} \mathrm{C}$. The trypsin digestion was stopped by the addition of formic acid at a final concentration of $5 \% 56,57$. Samples were desalted using $\mathrm{C} 18$ tips according to the manufacturer's instructions, resuspended in $10 \mu \mathrm{L}$ of $5 \%$ formic acid, and then analyzed by LC-MS/MS as described below.

\section{Mass spectrometry analysis}

The digested peptide mixture was desalted and concentrated using C18-packed pipette tips (Thermo Fisher) and fractionated online using a $75 \mu \mathrm{M}$ inner diameter fritted fused silica capillary column with a $5 \mu \mathrm{M}$ pulled electrospray tip and packed in-house with $15 \mathrm{~cm}$ of Luna C18(2) $3 \mu \mathrm{M}$ reversed phase particles. An EASY-nLC 1000 ultrahigh-pressure liquid chromatography (UHPLC) system (Thermo Fisher) was used to deliver the gradient and MS/MS spectra were collected on a Q Exactive mass spectrometer (Thermo Fisher) as described $^{58,59}$. Data analysis was carried out using the ProLuCID and DTASelect2 implemented in the Integrated Proteomics Pipeline - IP2 (Integrated Proteomics Applications, Inc., San Diego, CA $)^{60-62}$. To identify methylated peptides, a differential modification search was employed which considered variable mass shifts of 14.0157 (monomethylation), 28.0314 (dimethylation) and 42.0471 (trimethylation) on lysines and arginines to identify unlabeled peptide. The heavy search considered a static mass shift of 3.0189 $\mathrm{Da}$ from L-[methyl- $\left.\mathrm{D}_{3}\right]$-methionine and variable mass shift of 17.0346 (monomethylation), 34.0692 (dimethylation) and 51.1038 Da (trimethylation) on lysine or arginine. Database searches were conducted without enzyme specificity. Peptide identifications were filtered using DTASelect and required a unique fully-tryptic peptide with a spectrum-level false positive rate of $5 \%$ as estimated by a decoy database strategy ${ }^{63}$. The Skyline software package was used to manually evaluate the presence of heavy-light peptide doublet from extracted ion chromatograms generated for each peptide ${ }^{64}$.

For additional analysis to identify lysine, arginine, aspartate or glutamate containing methyl peptides, a differential modification search was employed which considered variable mass shifts of 14.0157 (monomethylation), 28.0314 (dimethylation) and 42.0471 (trimethylation) on lysines, arginines, aspartates, or glutamates to identify unlabeled peptide. The heavy search considered a static mass shift of 3.0189 Da on methionine corresponding to L[methyl- $\mathrm{D}_{3}$ ]-methionine and variable mass shift of 17.0346 (monomethylation), 34.0692 (dimethylation) and 51.1038 Da (trimethylation) on lysine, arginine, aspartate or glutamate. Database searches were conducted without enzyme specificity using the MSGF+ search algorithm ${ }^{65}$. The search results were analyzed using Percolator and filtered at a spectrumlevel q-value of $0.01^{66}$. Methyl site localization and site probability were determined using the PTMRS algorithm ${ }^{67}$. The Skyline software package was used to manually evaluate the presence of heavy-light peptide doublet from extracted ion chromatograms generated for each peptide ${ }^{64}$.

\section{Data Visualization and Structural Modeling}

Sequence logos were generated using WebLogo ${ }^{68}$. Sequences of 10 amino acids N-terminal and C-terminal of the methylated residue were inputted. The Venn diagram comparing 
candidates in the three protein fractions was prepared using a Venn diagram webtool (Bioinformatics \& Evolutionary Genomics, Ghent University). Structures were modeled using Protein Homology/analogy Recognition Engine V 2.0 $\left(\mathrm{Phyre}^{2}\right)^{69}$. Structural figures of the Phyre ${ }^{2}$ models were made using PyMol (Schrödinger, Inc).

\section{Comparison using UniProt Database}

Data obtained from this study and others like it were compared using proportional Venn diagrams. Proportional Venn diagrams were made from these methylated protein lists from cited studies using BioVenn ${ }^{70}$. The curated list from the Universal Protein Resource (UniProt) Database ${ }^{71}$ used for these comparisons was made as follows. The list was generated by first going to "keywords" in UniProt. From here, the category of PostTranslational Modification was selected and methylation specifically was chosen from the keywords navigation. Only "Reviewed" proteins were mapped to the keyword. The reviewed methylation keyword results were then filtered by organism (Saccharomyces cerevisiae (strain ATCC 204508 / S288c) (Baker's yeast)). This data set, once downloaded, comprised the "UniProt 2015" protein list. These comparisons are based on open reading frame of the methylated protein identified and not on the methylation site.

\section{RESULTS}

\section{Labeling of Yeast Strains with L-[methyl-D 3$]-$ methionine}

To detect methylated yeast mitochondrial proteins, we first attempted a large-scale study of mitochondrial fractions from wild type and methyltransferase knockout strains using MudPIT $^{72}$ without any isotopic labeling. This approach yielded many methylated peptide hits, but we were concerned that we did not consistently observe such peptides in various strains, leading us to question whether some or many of the hits could be false positives. We then optimized a heavy methyl SILAC protocol for labeling methyl groups in yeast proteins with methyl-deuterium labeled methionine. This method has been used with much success for unambiguously determining methylated peptides in a variety of human cell lines ${ }^{39,42-46}$. Yeast take up exogenous methionine rapidly ${ }^{73}$ and convert it into $S$-adenosyl-L-methionine (AdoMet) ${ }^{74}$, which is then used as the primary methyl donor by methyltransferases in the cell. Other methyl donors include $O^{6}$-methylguanine of DNA (used by Mgt1) ${ }^{75}, 5,10$ methylenetetrahydrafolate (used by $\mathrm{Cdc} 21)^{76}$, and $N^{5}$-methyltetrahydrofolate (used by Met6) ${ }^{77}$.

To optimize such labeling, it is important to shut down endogenous methionine biosynthesis that can dilute the label. The yeast wild-type BY4741 strain is already a methionine auxotroph with a deficiency in the MET15 gene (also known as MET17, MET25), encoding the enzyme forming the homocysteine precursor of methionine ${ }^{78}$. We first utilized this strain for heavy labeling with L-[methyl- $\left.\mathrm{D}_{3}\right]$-methionine. With heavy labeling alone, we found incomplete and inconsistent levels of incorporation in different peptides (Figure 1), resulting in variable levels of light methylation being present in the heavy-labeled culture. Due to the importance of having a 1:1 ratio of heavy and light proteins for the analysis of the peptides, the dilution of the label was problematic. If only the light form of the methylated peptide is present in the heavy culture (e.g. no label incorporation), then it will not be identified as 
methylated as there will be no heavy-light doublet in the MS1 spectra, only a light peak for that peptide from both the heavy and light cultures. It is likely here that unlabeled methyl groups can be introduced in the MET15 deletion strain via the Met6 methionine synthase from $N^{5}$-methyltetrahydrofolate ${ }^{77,79}$. MET6 gene deletion has a mild phenotype aside from methionine auxotrophy ${ }^{80}$. We have observed that met6 6 cells grew similarly to BY4741 cells in synthetic non-fermentable medium, allowing for mitochondrial fractionation. We thus utilized a strain containing a MET6 deletion mutation that prevents the methylation of homocysteine to methionine ${ }^{77}$. The use of this strain resulted in increased efficiency in labeling (Figure 1).

The met6 $\Delta$ cells were thus grown in both light and heavy media under respiratory conditions, harvested, and then extracts separated into three protein fractions: mitochondria, mitochondrial ribosomal proteins, and cytoplasmic ribosomal proteins as described in the "Materials and Methods" section. The latter fraction was prepared as a positive control since the methylation status of these proteins has been well established ${ }^{2}$. The resulting heavy and light protein fractions were combined in a 1:1 ratio for mass spectrometric analysis. A total of three independent cell labeling experiments were done; three independently prepared fractions of the mitochondria and of the cytoplasmic ribosomes and two independently prepared fractions of mitochondrial ribosomal proteins were digested with a trypsin/Lys-C protease mixture and analyzed by mass spectrometry as described in the "Materials and Methods" section.

\section{Identification of Peptides Containing Methylated Residues}

To analyze the collected peptide mass spectral data for methylated peptides, two ProLuCID searches were set up for each protein fraction replicate in the IP2 platform as described in the "Materials and Methods" section. Both were closed searches for methylation of lysine (mono-, di-, and tri-) and arginine (mono-, and di-) specifically. One differential modification search considered only "light" peptides: peptides with a variable mass shift of 14.0157 (monomethylation), 28.0314 (dimethylation), and 42.0471 (trimethylation) Da. The other differential modification search considered "heavy" peptides: peptides with a static mass shift of 3.0189 Da (from L-[methyl- $\left.\mathrm{D}_{3}\right]$-methionine) and variable mass shifts of 17.0346 (monomethylation), 34.0692 (dimethylation), and 51.1038 Da (trimethylation). We also performed additional searches to include the detection of methylated aspartate and glutamate residues as described in the Materials and Methods. The peptide lists from these searches were then exported into Skyline libraries for evaluation of the presence of the expected heavy-light doublet in the extracted precursor ion chromatograms generated from each identified light/heavy methylated peptide pair. An example of this is seen in Figure $2 \mathrm{~A}$. We confirmed the heavy-light doublet by matching the observed isotope distribution of each precursor ion with the theoretical distribution (Figure 2B). Novel methylated peptides were further evaluated based on their presence in multiple replicates and the quality of their MS/MS spectra generated by HCD fragmentation.

From the data in all eight mass spectrometric analyses (two or three replicates from each of the three protein fractions), 112 peptides were identified using IP2 and Skyline as having a mass shift consistent with methylation but did not show the expected light/heavy doublet (an 
example is shown in Figure 2C and 2D; peptides are listed in Table S-1, tab 2). However, we did identify 36 peptides from 20 proteins in these experiments that displayed the expected light/heavy doublet (Table S-1, tab 3). Thus, only $25 \%$ of peptides identified as methylated by the ProLuCID search algorithm were validated using heavy methyl SILAC. In rare cases, AdoMet is not used as a methyl donor ${ }^{75,76}$. However, it appears that many of these identifications may be false positives. Our results suggest that studies that do not validate methylated peptide identifications using heavy methyl SILAC or other quantifiable methods may overestimate the number of methylation sites occurring in the cell, potentially reporting methylation sites that are not present.

Here, we report 26 methylation sites on 20 proteins across the three protein fractions. There was little overlap between methylated candidates in the three protein fractions as seen in Figure 3. Of the proteins that overlapped, two were highly abundant, Ssa2 and Ssa4, which are part of the Hsp70 family of proteins, and two that are known to be methylated as well as abundant, Tef1/2 (eEF1A) and Rpl42ab. These results indicate that discrete pools of methylated proteins exist in the cytoplasm and the mitochondria.

\section{Validation of Approach by Analysis of the Cytoplasmic Ribosomal Fraction}

The cytoplasmic ribosomal protein fraction was used as a reference set for the heavy methyl SILAC method (Table 1). We validated four sites on three ribosomal proteins: dimethyl $\mathrm{K} 106$ and K110 on Rpl23ab ${ }^{81}$, monomethyl K55 on Rpl42ab ${ }^{82}$, and monomethyl R67 on

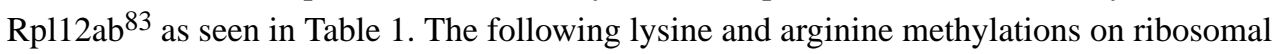
proteins were not found in our analysis: trimethyl K3 Rpl12ab ${ }^{82}$, monomethyl K46 Rpl1 ${ }^{84}$, monomethyl K40 on Rp142ab ${ }^{82}$, mono- or dimethyl R11 on Rps ${ }^{85}$, and monomethyl R145 on Rps $3^{85}$. It is unclear if these sites were missed due to incomplete sampling of precursor ions during our data-dependent acquisition method or due to the absence of the modification under respiratory rather than fermentative growth conditions. It would be intriguing if these sites were required for function under fermentation, but not under respiratory conditions. It is also possible that the trimethyl $\mathrm{K} 3$ site on Rp112ab may have been missed because it would be found in a peptide with a modified dimethylproline residue at position $1^{86}$ which was not considered during the database search. Arginine methylation at position 11 of Rps2 is substoichiometric ${ }^{87}$, which may be why this modification was missed. We also identified previously unseen methylation variants of Rpl23ab, including trimethylation and monomethylation at K106 and K110. These forms are distinct from the well-characterized dimethyl K106/dimethyl K110 species (Table 1, Figure S-1, Figure S-2). However, such methylation site assignments were based primarily on the presence of a single sitedetermining ion and may represent sites that are mislocalized by the search algorithm.

We also found a number of ribosome-associated methylated proteins in this fraction. Eukaryotic elongation factor 1A (eEF1A), encoded by TEF1/TEF2, is known to be highly methylated on five lysine residues: monomethyl K30, trimethyl K79, dimethyl K316, monomethyl K390, and a C-terminal lysine methyl ester ${ }^{88,89}$. Our approach here identified three out of the five sites, as seen in Figure 4: monomethyl K30, trimethyl K79, and monomethyl K390, the latter of which may be sub-stoichiometric and at lower occupancy than the other methylated lysines on $\mathrm{eEF} 1 \mathrm{~A}^{90}$. We also identified a peptide containing the 
potentially novel monomethylation of $\mathrm{K} 30$ and $\mathrm{K} 35$. Based on the fragmentation pattern for this peptide (Figure S-1), however, this methylation site assignment could be incorrect as the site-determining ions support dimethylation of $\mathrm{K} 30$ as well. The other elongation factor methylation sites, trimethyl K509 and dimethyl K613 on EF2 and trimethyl K187, K196, and $\mathrm{K} 789$ on $\mathrm{EF}^{91}{ }^{91}$, were not identified; again, it is unclear whether these sites are not methylated under respiratory conditions or were simply missed in the analysis. We also detected methylation on the Ded1 RNA helicase required for translation initiation for yeast mRNA $^{92}$. Here, we confirm the dimethyl R51 site previously found ${ }^{93}$.

Finally, we were able to detect methylation sites on several other proteins. We were able to confirm the dimethylation of abundant histone $\mathrm{H} 3$ protein (Hht1) at K3794 that may have contaminated the cytoplasmic ribosome preparation. We additionally find a potentially novel monomethyl K38 on histone H3 (Figure S-1). K38 methylation is supported by two diagnostic site-determining ions, so further investigation is needed. Importantly, novel methylation sites are identified as follows: monomethyl K422 on Ssa4, monomethyl K421 on Ssa2, and dimethyl R89 on Hsp26. Ssa4, Ssa2, and Hsp26 are all cytoplasmic heat-shock induced chaperones ${ }^{95,96}$ that potentially co-purified with cytoplasmic ribosomal proteins through interaction with nascent polypeptide chains.

As described above and in the Materials and Methods, known methylation sites Known methylation sites were validated with additional analyses for lysine, arginine, glutamate, and aspartate methylation, with the exception of Rpl23ab where the first dimethylation event has an even probability to be on K106 or E108 (Table 1). Additionally, although the majority of peptides gave unambiguous assignment of the trimethyl to K79 via site probability, a portion of the peptides did have the probability split between K79 and E81. As this methylation is well-characterized ${ }^{88}$, we can determine that the trimethylation occurs on K79.

Many of the novel methylated peptides were not identified in the additional analysis, including Rpl23ab, Histone H3, eEF1a, and Ssa2/4. Hsp26, containing a C-terminal dimethyl arginine on R89, has a region of likely dimethylation, spanning from D64 to D77. Based on a spectrum to spectrum comparison between the two searches, the likely residues containing the methylation due to probability are D74 and D76, as they share an equal probability. As dimethyl aspartate is highly unlikely, the methylation possibly occurs on R66.

\section{Analysis of the Mitochondrial Ribosomal Fraction}

In the mitochondrial ribosomal protein fraction, three mitochondrial ribosomal proteins were identified as methylated: Mnp1, Mrpl4, and Mrpl40 (Table 2, Figure 5, Figure S-2). Like their cytoplasmic counterparts, mitochondrial ribosomal proteins are also subject to this modification. Mnp1, Mrp140, and Mrpl4 are all large subunit components ${ }^{97}$. Methylation of mitochondrial ribosomal protein L11 has been reported in Arabidopsis thaliana ${ }^{98}$; we find no evidence for the methylation of the corresponding yeast protein in our study. A number of methylation sites of mitochondrial ribosomal proteins were also reported in Trypanosoma bruce $^{22}$, but confirmatory isotope labeling was not used in that study. The T. brucei homolog of Mnp1, Tb927.7.4550, was found to be methylated on an arginine residue in that study. 
The novel methylation sites found in the mitochondrial ribosomal protein fraction are: monomethyl R55 on Pdb1, monomethyl K144 on Pst2, monomethyl K558 on Ecm10, monomethyl K422 on Ssa4, dimethyl K56 on Mnp1, monomethyl K49 on Rps2, monomethyl K421 on Ssa2, monomethyl R204 on Mrp14, monomethyl R260 on Lat 1, dimethyl K340 on Lat1, and monomethyl K186 on Mrp140. The presence of methylated histone $\mathrm{H} 3$ is a possible sign of nuclear contamination. There was expected cytoplasmic ribosomal protein contamination in the mitochondrial ribosomal protein fraction as demonstrated by the presence of methylated peptides from Rpl23ab, eEF1A, Rp112ab, Rp142ab, and a novel methylation on Rps2 (Table 2).

Analyzing the data for aspartate and glutamate methylation in addition to lysine and arginine methylation yielded additional confirmation of known sites in this fraction with the exception of methyl peptides from eEF1a and Rpl23ab. Though alternative, and novel, methylation states are identified with opening up the search for D/E methylation (Table 2), the known methyl peptide containing dimethyl K106 and dimethyl K110 on Rp123ab was no longer identified. The peptide identified corresponded better to the novel trimethyl K106, monomethyl K110 peptide identified though it was found in the scan number for the dimethyl K106 and K110 peptide. The methyl peptide containing monomethyl K30 had equal probability for the monomethylation to occur on a nearby aspartate (D35). However, as mentioned previously, given the well-studied nature of eEF1a lysine modifications, it is more likely that the methylated residue truly is $\mathrm{K} 30^{88}$. Additionally, the novel methylation of histone $\mathrm{H} 3$ on K38 appears to be more likely on the known residue of K37.

While the methyl peptides were not identified for any of the three MRPs, a shortened methyl peptide that did not contain K56 had a high probability of methylation on E68 on Mnp1. Similarly, the methyl peptide containing R260 on Lat 1 was not identified while the peptide containing K340 had equal probability of the dimethyl on K340 or D343. The methylation of Pdb1 cannot be clearly assigned to R55 in this fraction, but spans a region from E51 to D58. For the corresponding peptides from the previous search, it appears to be an equal probability of methylation on either E51 or E52. Neither of the exact matching novel methyl peptides of trimethyl/monomethyl K106 and monomethyl/trimethyl K110 on Rp123ab were identified. Similar peptides yielded methyl site probabilities that indicated possibility of E108 methylation. There is stronger basis for trimethyl K106 and monomethyl K110 based on probability. However, within this search, all methylations were initially misassigned to E96 and D97.

Clear site assignments occurred for the methyl peptides of Ssa2/4, Pst2, Ecm10, and Rps2. While the original site assignment for Ssa2/4 was K421/422, the additional analysis gave this methyl peptide a high probability for methylation on E423/E424. Similarly, Pst2 monomethylation has a high probability on E121 instead of K144. Ecm10 monomethylation likely occurs on K558 having been identified in the search for just K/R and in K/R/D/E with a high probability for that residue. The same is true for monomethylation of Rps2 at K49, which is a new modification for the ribosomal protein that could be required for the ribosome under respiratory conditions. 


\section{Analysis of Methylated Proteins in the Mitochondrial Fraction}

The majority of candidate methyl peptides identified were mitochondrial in origin as seen in Table 3 (Figure S-3). The newly identified sites in this protein fraction were as follows: monomethyl R55 on Pdb1, trimethyl K308 on Ald5, monomethyl K422 on Ssa4, monomethyl K421 on Ssa2, trimethyl K490 on Hsp60, trimethyl K345 on Ald4, and dimethyl K360 on Aco1. None of these have been previously identified. Methylated peptides from both Rp142ab and eEF1A were also identified, likely due to the abundance of these proteins.

In additional database searches for methyl lysine, arginine, glutamate, and aspartate, these methylpeptides were confirmed albeit putatively on alternative sites (Table 3). It is apparent from the fragmentation pattern of the methyl peptide containing the monomethyl arginine on Pdb1 as well as the methyl site probabilities that the methylation cannot be localized. Here, we are confident given results from the MRP fraction that the peptide contains a methylation mark; however, it cannot be assigned to R55, but confined to the methylatable residues from E51 to D58 as in the MRP fraction. On the other hand, the trimethylation of K308 on the methylpeptide from Ald5 appears to be correctly assigned based on methyl site probabilities. This occurred for K490 on Hsp60 as well. The potential methylations of Ssa2/4 and Aco1 present an interesting divergence from the previous search algorithm. The monomethylation on Ssa2/4 was assigned to E423/4 with high probability as opposed to K421/422. The dimethyl on Aco1 was not able to be localized based on probability. Though the exact corresponding peptide from the original search was not identified, similar peptides contained equal probability on the methylatable residues from D323 to E345. It is clear that two methyl groups are present on this peptide, whether as one dimethyl lysine or two monomethylations as dimethyl $\mathrm{D}$ or $\mathrm{E}$ is not biologically possible.

Clear assignments were seen for known sites of monomethyl K55 on Rpl42ab and monomethyl K30 on eEF1a with high methyl site probabilities. This is to be expected as 1) these methylation events are unambiguously on lysine residues and 2) these methyl peptides contain few, if any, acidic residues for assignment. The assignment of trimethyl 79 on eEF1a in the methyl peptide was less clear. While the exact matching peptide from the original search carried unambiguous probability for trimethylation solely on $\mathrm{K} 79$, in most of the methyl peptides identified in the K/R/D/E search, the methyl site probability split for localization to either K79 or E81. However, fragmentation patterns support localization at $\mathrm{K} 79$ as does the expansive literature on eEF1a methylation ${ }^{88,89}$.

Ssa2 is largely cytoplasmic and nuclear, but has been found to localize to the mitochondria as well ${ }^{21,99}$. Whether the methylation of K422/E424 or K421/E423 is on Ssa2, Ssa4, or both proteins is unclear as it is in a conserved region of the proteins and the resulting peptide is identical, as seen in Figure 6. As Ssa2 potentially localizes to the mitochondria, the presence of $\mathrm{Ssa} 2$ and $\mathrm{Ssa} 4$ in this fraction could be due to that localization. This might also suggest that the methylation is on Ssa2. However, both Ssa2 and Ssa4 may also represent some cytoplasmic or ribosomal contamination as they were found in that fraction as well. Additionally, the arginine monomethylation site determined in humans (HsR669, ScR466/7) ${ }^{100}$ was not found in this or any fraction. 


\section{Sequence Specificity of Methylation}

While this study focused primarily arginine and lysine methylation, it is possible that other methylation sites exist on other residues such as histidine, glutamine or asparagine ${ }^{101-103}$, although these are much less common than arginine and lysine. However, based on the original analysis of these data, it appears that lysine methylation could be more prevalent in protein fractions examined as seen in Table 1 . This could be due to the fact that this study sought to determine global mitochondrial methylation whereas the substrates for arginine methyltransferases (Rmt1, Rmt2, Sfm1, and Hsl7) in yeast are localized in the cytoplasm and nucleus ${ }^{104}$. Additionally, there does not appear to be any sequence specificity for lysine (Figure 7A and 7B) or arginine (Figure 7C) methylated residues determined in this study. Again, the common arginine methylation motif (RGG), which Rmt1 is known to methylate ${ }^{105}$ is not seen, except in the known Rmt1 substrate, Ded1, presumably because no other methylated arginine site is an Rmt 1 target. Thus, structural elements appear to be required for the modification at these sites in place of or in addition to the amino acid sequence adjacent to the methylatable residue. Based on structural models, most of the newly identified methylation sites are surface exposed in structurally accessible regions of the proteins (Table S-1, tab 1, Figure S-4). Surface exposed residues are more likely to be accessible as substrates for a methyltransferase.

\section{DISCUSSION}

\section{Approach}

Our study presents the first look at global protein methylation in the mitochondria of Saccharomyces cerevisiae through the use of heavy methyl SILAC. This work identifies potential substrates for the mitochondrially localized candidate protein methyltransferases. Our finding that mitochondrial ribosomal proteins specifically are methylated is consistent not only with reports of methylated mitochondrial ribosomal proteins from trypanosomes and Arabidopsis, but as a hallmark modification for ribosomal proteins as a whole ${ }^{20}$. Identification of these methylation reactions may offer insight into the functional and regulatory detail of mitochondrial translation, metabolism, control, and dynamics.

Many other proteomic studies have attempted to characterize the methyl proteome of $S$. cerevisiae. Even with validation techniques, such as isotopic labeling, there is little to no overlap between methylated proteins determined from established methyl proteome studies and those curated from Uniprot (Figure 8, Table S-2). It thus appears that the methylation sites identified in any given study represent only a fraction of the methylation that occurs on the cellular level. The lack of overlap with the study presented here is likely also due to our focus on analyzing mitochondrial fractions rather than the entire proteome.

Opening searches up to methyl $\mathrm{E}$ and $\mathrm{D}$ resulted in more $\mathrm{E}$ and $\mathrm{D}$ assignments than $\mathrm{K} / \mathrm{R}$. Many may not be biologically relevant, for example trimethyl E81 as opposed to trimethyl K79 on eEF1a, which is a known and well-characterized modification. However, many monomethylation events on glutamate or aspartate appear to be possible as on Pdb1 or $\mathrm{Ssa} / 4$. There are few examples of acidic residue methylation in $S$. cerevisiae. Pab1 in yeast and other organisms has been reported to be methylated on various glutamate residues 
needed for function ${ }^{106}$. There have been whole cell investigations of glutamate and aspartate methylation in yeast. However, these experiments performed were dependent on in-gel digests and it is unclear if methanol was avoided in sample preparation ${ }^{103}$. Additionally, the only well-characterized example of an acidic residue methyltransferase is CheR in the prokaryote chemotaxis signaling system ${ }^{107}$. This does not have a homolog in yeast. Although there are many putative methyltransferase with substrates that have yet to be identified ${ }^{9}$, there currently is no identified glutamate or aspartate methyltransferase in yeast. While possible, it seems unlikely newly identified sites are indeed localized on D/E residues, unless acidic residue methyl esterification may be more common in the mitochondria. Until all of the methyltransferases in yeast have been characterized, this remains a possibility.

\section{Mitochondrial Methylation}

Methylated mitochondrial protein candidates serve a variety of functions. Mitochondrial fraction candidates are involved in metabolism or mitochondrial genome maintenance in some capacity. Both Ald4 and Ald5 are mitochondrial aldehyde dehydrogenases. Constitutively expressed Ald5 is the minor isoform, while Ald4 is the major isoform ${ }^{108}$. Pdb1 is the E1 beta subunit of pyruvate dehydrogenase ${ }^{109}$. Ald4 and Pdb1, along with candidates Hsp60 and Aco1, are mitochondrial nucleoid proteins, suggesting a role of methylation in the maintenance of the mitochondrial genome $e^{110,111}$. Interestingly, of these, the aconitase Aco1 ${ }^{112}$ is a multifunctional protein that acts not only in the TCA cycle, but also in mtDNA maintenance in an enzyme activity-independent manner. Previous studies suggest that Aco1 couples metabolism to mitochondrial genome maintenance ${ }^{110,113}$. Though Aco1 is known to be phosphorylated ${ }^{114-116}$, it is unclear how this modulates Aco1 function. Coupled now with Aco1 methylation, further work is needed to understand how its many post-translational modifications affect its functions.

Methylation may certainly affect translation, similar to the cytoplasmic translational apparatus. Mnp1 and Mrpl4 have essential functions in mitochondrial translation 97,117,118. Additionally, Mnp1, the L $7 / 12$ homolog ${ }^{119}$ on the yeast mitochondrial ribosome, is not only vital for mitochondrial translation, but for cell cycle progression as well ${ }^{120}$. Gene deletion of Mnp1 not only affects respiratory growth, but is lethal under fermentative conditions as well. Methylation of these proteins could represent a point of regulation of mitochondrial translation or be important for assembly or function as is the case for cytoplasmic ribosomal proteins ${ }^{101,121}$.

Although not a mitochondrial ribosomal protein, Lat1, the E2 component of the pyruvate dehydrogenase complex ${ }^{122}$, was recently found to associate with mitochondrial ribosomes $^{123}$. Our finding of methylated Lat1 peptides in the MRP fraction suggests that Lat 1 does indeed interact with the mitochondrial ribosomes. Other potentially mitochondrial ribosome associated proteins were Pdb1, also the E1 beta subunit of pyruvate dehydrogenase ${ }^{109}$, Ecm10, one of the mitochondrial Hsp70s ${ }^{124}$, and Pst2, a protein of unknown function found in mitochondrial proteome studies ${ }^{125}$. Like Lat1, Ecm10 and Pdb1 may also interact with mitochondrial ribosomes, which may explain their presence in this fraction. Both Ecm10 and Pdb1 localize to mitochondrial nucleoids ${ }^{110,126}$. It has been recently discovered that mitochondrial ribosomes form complexes at mitochondrial 
nucleoids, termed MIOREX complexes ${ }^{123}$. The presence of Ecm10, Pdb1, and Lat1 in the MRP fraction may be indicative of these MIOREX complexes.

\section{Chaperone Methylation and the "Chaperone Code"}

Many molecular chaperone proteins were identified as methylated in this study, including Hsp60 and Ssa2/4. Hsp60 is the major chaperone in the mitochondria. In humans, HSPD1, the Hsp60 homolog, interacts with both ETFBKMT and METTL21B ${ }^{127}$. ETFBKMT and METTL21B are lysine methyltransferases; this interaction could facilitate a methylation reaction with HSPD1 as a substrate. There are no known interactions of Hsp60 with methyltransferases in yeast.

Methylation of Ssa2/4 is unexpected as the methylation did not occur on the conserved methylation site that was previously reported for Hsp70 proteins in human cells ${ }^{127-130}$. Methylation of Hsp70 proteins in humans has been implicated as part of a "chaperone code" 131 and enhanced methylation is often seen in cancer ${ }^{130}$. However, this site, K556 in Ssa2 and K559 in Ssa4, has been reported as unmethylated in yeast ${ }^{90}$. We also did not find evidence of lysine 556/559 methylation under respiratory conditions. Monomethylation of K421 or K422 under respiratory conditions presents a unique departure from their human counterparts, particularly if this site is truly on E423 or E424. Monomethylation on lysine $421 / 422$ or E423/424 is novel and presents a divergence from the known methylation state in human Hsps. As the conserved methylation has been implicated in human malignancies ${ }^{130}$, further study is required to determine whether this novel methylation site affects Hsp70 function as well.

\section{Conclusion}

Importantly, we were able to adapt heavy methyl SILAC for use in a commercially available met64 strain of yeast. While we have found that methyl proteome studies that do not use isotope labeling have the propensity to overestimate biologically relevant methylations, current heavy methyl SILAC studies using the $M E T \sigma^{+}$BY4741 strain $^{15,48}$ likely underestimate the methylations reported. This is due to the fact that Met6 can catalyze the formation of light methionine using $N^{5}$-methyltetrahydrofolate. Gene deletion of MET6 ensures that heavy cultures will contain only heavy methylated proteins. It is our hope that with this knowledge, heavy methyl SILAC can be more widely used in the yeast methyl proteome community.

\section{Supplementary Material}

Refer to Web version on PubMed Central for supplementary material.

\section{ACKNOWLEDGMENTS}

We thank Dr. Catherine Clarke, Dr. Carla Koehler, and members of their laboratories (UCLA) for protocols and advice on purifying mitochondrial proteins. We also thank Dr. Qais Al-Hadid and Dr. Maria Dzialo for their helpful advice and initial work on this project. This work was supported by National Institutes of Health Grants GM026020 (S.G.C.), GM089778 (J.A.W.) and GM112763 (J.A.W.). K.E.C. and W.D.B. were supported by the Ruth L. Kirschstein National Research Service Award GM007185 from the National Institutes of Health. 
ABBREVIATIONS

$\begin{array}{ll}\text { Cyto RP } & \text { Cytoplasmic ribosomal proteins } \\ \text { Mito } & \text { Mitochondrial } \\ \text { MRP } & \text { Mitochondrial ribosomal proteins } \\ \text { MudPIT } & \text { multidimensional protein identification technology } \\ \text { SILAC } & \text { stable isotope labeling by amino acids in cell culture }\end{array}$

\section{REFERENCES}

(1). Walsh, C. Posttranslational Modification of Proteins: Expanding Nature's Inventory. Roberts and Company Publishers; 2006. Protein Methylation; p. 121-150.

(2). Clarke SG. Protein methylation at the surface and buried deep: thinking outside the histone box. Trends Biochem. Sci. 2013; 38(5):243-252. [PubMed: 23490039]

(3). Carlson SM, Gozani O. Emerging technologies to map the protein methylome. J. Mol. Biol. 2014; 426(20):3350-3362. [PubMed: 24805349]

(4). Lanouette S, Mongeon V, Figeys D, Couture J-F. The functional diversity of protein lysine methylation. Mol. Syst. Biol. 2014; 10(4):724. [PubMed: 24714364]

(5). Biggar KK, Li SS-C. Non-histone protein methylation as a regulator of cellular signalling and function. Nat. Rev. Mol. Cell Biol. 2015; 16(1):5-17. [PubMed: 25491103]

(6). Petrossian T, Clarke S. Bioinformatic Identification of Novel Methyltransferases. Epigenomics. 2009; 1(1):163-175. [PubMed: 20582239]

(7). Petrossian TC, Clarke SG. Multiple Motif Scanning to identify methyltransferases from the yeast proteome. Mol. Cell. Proteomics. 2009; 8(7):1516-1526. [PubMed: 19351663]

(8). Wlodarski T, Kutner J, Towpik J, Knizewski L, Rychlewski L, Kudlicki A, Rowicka M, Dziembowski A, Ginalski K. Comprehensive structural and substrate specificity classification of the Saccharomyces cerevisiae methyltransferome. PLoS One. 2011; 6(8):e23168. [PubMed: 21858014]

(9). Szczepińska T, Kutner J, Kopczyński M, Pawłowski K, Dziembowski A, Kudlicki A, Ginalski K, Rowicka M. Probabilistic approach to predicting substrate specificity of methyltransferases. PLoS Comput. Biol. 2014; 10(3):e1003514. [PubMed: 24651469]

(10). Kachroo AH, Laurent JM, Yellman CM, Meyer AG, Wilke CO, Marcotte EM. Systematic humanization of yeast genes reveals conserved functions and genetic modularity. Science. 2015; 348(6237):921-925. [PubMed: 25999509]

(11). Sprung R, Chen Y, Zhang K, Cheng D, Zhang T, Peng J, Zhao Y. Identification and validation of eukaryotic aspartate and glutamate methylation in proteins. J. Proteome Res. 2008; 7(3):10011006. [PubMed: 18220335]

(12). Pang CNI, Gasteiger E, Wilkins MR. Identification of arginine- and lysine-methylation in the proteome of Saccharomyces cerevisiae and its functional implications. BMC Genomics. 2010; 11(1):92. [PubMed: 20137074]

(13). Low JKK, Hart-Smith G, Erce MA, Wilkins MR. Analysis of the proteome of Saccharomyces cerevisiae for methylarginine. J. Proteome Res. 2013; 12(9):3884-3899. [PubMed: 23865587]

(14). Wang K, Zhou YJ, Liu H, Cheng K, Mao J, Wang F, Liu W, Ye M, Zhao ZK, Zou H. Proteomic analysis of protein methylation in the yeast Saccharomyces cerevisiae. J. Proteomics. 2015; 114:226-233. [PubMed: 25109467]

(15). Plank M, Fischer R, Geoghegan V, Charles PD, Konietzny R, Acuto O, Pears C, Schofield CJ, Kessler BM. Expanding the yeast protein arginine methylome. Proteomics. 2015; 15(18):32323243. [PubMed: 26046779]

(16). Lasserre J-P, Dautant A, Aiyar RS, Kucharczyk R, Glatigny A, Tribouillard-Tanvier D, Rytka J, Blondel M, Skoczen N, Reynier P, et al. Yeast as a system for modeling mitochondrial disease 
mechanisms and discovering therapies. Dis. Model. Mech. 2015; 8(6):509-526. [PubMed: 26035862]

(17). Le DD, Fujimori DG. Protein and nucleic acid methylating enzymes: mechanisms and regulation. Curr. Opin. Chem. Biol. 2012; 16(5-6):507-515. [PubMed: 23085277]

(18). Del Rizzo PA, Trievel RC. Molecular basis for substrate recognition by lysine methyltransferases and demethylases. Biochim. Biophys. Acta. 2014; 1839(12):1404-1415. [PubMed: 24946978]

(19). Bedford MT. Arginine methylation at a glance. J. Cell Sci. 2007; 120:4243-4246. Pt 24. [PubMed: 18057026]

(20). Polevoda B, Sherman F. Methylation of proteins involved in translation. Mol. Microbiol. 2007; 65(3):590-606. [PubMed: 17610498]

(21). Renvoisé M, Bonhomme L, Davanture M, Valot B, Zivy M, Lemaire C. Quantitative variations of the mitochondrial proteome and phosphoproteome during fermentative and respiratory growth in Saccharomyces cerevisiae. J. Proteomics. 2014; 106:140-150. [PubMed: 24769239]

(22). Fisk JC, Li J, Wang H, Aletta JM, Qu J, Read LK. Proteomic analysis reveals diverse classes of arginine methylproteins in mitochondria of trypanosomes. Mol. Cell. Proteomics. 2013; 12(2): 302-311. [PubMed: 23152538]

(23). Polevoda B, Martzen MR, Das B, Phizicky EM, Sherman F. Cytochrome c methyltransferase, Ctm1p, of yeast. J. Biol. Chem. 2000; 275(27):20508-20513. [PubMed: 10791961]

(24). Park KS, Frost B, Tuck M, Ho LL, Kim S, Paik WK. Enzymatic methylation of in vitro synthesized apocytochrome c enhances its transport into mitochondria. J. Biol. Chem. 1987; 262(30):14702-14708. [PubMed: 2822698]

(25). Cessay KJ, Bergman LW, Tuck MT. Further investigations regarding the role of trimethyllysine for cytochrome c uptake into mitochondria. Int. J. Biochem. 1991; 23(7-8):761-768. [PubMed: 1650724]

(26). Farooqui J, Kim S, Paik WK. In vivo studies on yeast cytochrome c methylation in relation to protein synthesis. J. Biol. Chem. 1980; 255(10):4468-4473. [PubMed: 6246072]

(27). Winter DL, Abeygunawardena D, Hart-Smith G, Erce MA, Wilkins MR. Lysine methylation modulates the protein-protein interactions of yeast cytochrome C Cyc1p. Proteomics. 2015; 15(13):2166-2176. [PubMed: 25755154]

(28). Kluck RM, Ellerby LM, Ellerby HM, Naiem S, Yaffe MP, Margoliash E, Bredesen D, Mauk AG, Sherman F, Newmeyer DD. Determinants of cytochrome c pro-apoptotic activity. The role of lysine 72 trimethylation. J. Biol. Chem. 2000; 275(21):16127-16133. [PubMed: 10821864]

(29). Polevoda B, Span L, Sherman F. The yeast translation release factors Mrf1p and Sup45p (eRF1) are methylated, respectively, by the methyltransferases Mtq1p and Mtq2p. J. Biol. Chem. 2006; 281(5):2562-2571. [PubMed: 16321977]

(30). Saveanu C, Fromont-Racine M, Harington A, Ricard F, Namane A, Jacquier A. Identification of 12 new yeast mitochondrial ribosomal proteins including 6 that have no prokaryotic homologues. J. Biol. Chem. 2001; 276(19):15861-15867. [PubMed: 11278769]

(31). Lisowsky T, Michaelis G. Mutations in the genes for mitochondrial RNA polymerase and a second mitochondrial transcription factor of Saccharomyces cerevisiae. Mol. Gen. Genet. 1989; 219(1-2):125-128. [PubMed: 2693937]

(32). Lemaire C, Guibet-Grandmougin F, Angles D, Dujardin G, Bonnefoy N. A yeast mitochondrial membrane methyltransferase-like protein can compensate for oxa1 mutations. J. Biol. Chem. 2004; 279(46):47464-47472. [PubMed: 15355998]

(33). Huh W-K, Falvo JV, Gerke LC, Carroll AS, Howson RW, Weissman JS, O'Shea EK. Global analysis of protein localization in budding yeast. Nature. 2003; 425(6959):686-691. [PubMed: 14562095]

(34). Chacinska A, Koehler CM, Milenkovic D, Lithgow T, Pfanner N. Importing mitochondrial proteins: machineries and mechanisms. Cell. 2009; 138(4):628-644. [PubMed: 19703392]

(35). Erce MA, Pang CNI, Hart-Smith G, Wilkins MR. The methylproteome and the intracellular methylation network. Proteomics. 2012; 12(4-5):564-586. [PubMed: 22246820]

(36). Jung SY, Li Y, Wang Y, Chen Y, Zhao Y, Qin J. Complications in the assignment of 14 and $28 \mathrm{Da}$ mass shift detected by mass spectrometry as in vivo methylation from endogenous proteins. Anal. Chem. 2008; 80(5):1721-1729. [PubMed: 18247584] 
(37). Chen G, Liu H, Wang X, Li Z. In vitro methylation by methanol: proteomic screening and prevalence investigation. Anal. Chim. Acta. 2010; 661(1):67-75. [PubMed: 20113717]

(38). Xing G, Zhang J, Chen Y, Zhao Y. Identification of four novel types of in vitro protein modifications. J. Proteome Res. 2008; 7(10):4603-4608. [PubMed: 18767873]

(39). Ong S-E, Mittler G, Mann M. Identifying and quantifying in vivo methylation sites by heavy methyl SILAC. Nat. Methods. 2004; 1(2):119-126. [PubMed: 15782174]

(40). Chen Y, Zhang J, Xing G, Zhao Y. Mascot-derived false positive peptide identifications revealed by manual analysis of tandem mass spectra. J. Proteome Res. 2009; 8(6):3141-3147. [PubMed: 19368407]

(41). Michalski A, Cox J, Mann M. More than 100,000 detectable peptide species elute in single shotgun proteomics runs but the majority is inaccessible to data-dependent LC-MS/MS. J. Proteome Res. 2011; 10(4):1785-1793. [PubMed: 21309581]

(42). Zee BM, Levin RS, Xu B, LeRoy G, Wingreen NS, Garcia BA. In vivo residue-specific histone methylation dynamics. J. Biol. Chem. 2010; 285(5):3341-3350. [PubMed: 19940157]

(43). Bremang M, Cuomo A, Agresta AM, Stugiewicz M, Spadotto V, Bonaldi T. Mass spectrometrybased identification and characterisation of lysine and arginine methylation in the human proteome. Mol. Biosyst. 2013; 9(9):2231-2247. [PubMed: 23748837]

(44). Moore KE, Carlson SM, Camp ND, Cheung P, James RG, Chua KF, Wolf-Yadlin A, Gozani O. A general molecular affinity strategy for global detection and proteomic analysis of lysine methylation. Mol. Cell. 2013; 50(3):444-456. [PubMed: 23583077]

(45). Cao X-J, Arnaudo AM, Garcia BA. Large-scale global identification of protein lysine methylation in vivo. Epigenetics. 2013; 8(5):477-485. [PubMed: 23644510]

(46). O'Connor CM, DiMaggio PA, Shenk T, Garcia BA. Quantitative proteomic discovery of dynamic epigenome changes that control human cytomegalovirus (HCMV) infection. Mol. Cell. Proteomics. 2014; 13(9):2399-2410. [PubMed: 24987098]

(47). Uhlmann T, Geoghegan VL, Thomas B, Ridlova G, Trudgian DC, Acuto O. A Method for Largescale Identification of Protein Arginine Methylation. Mol. Cell. Proteomics. 2012; 11(11):14891499. [PubMed: 22865923]

(48). Yagoub D, Hart-Smith G, Moecking J, Erce MA, Wilkins MR. Yeast proteins Gar1p, Nop1p, Npl3p, Nsr1p and Rps2p are natively methylated and are substrates of the arginine methyltransferase Hmt1p. Proteomics. 2015; 15(18):3209-3218. [PubMed: 26081071]

(49). Hart-Smith G, Yagoub D, Tay AP, Pickford R, Wilkins MR. Large-scale mass spectrometrybased identifications of enzyme-mediated protein methylation are subject to high false discovery rates. Mol. Cell. Proteomics. 2016; 15(3):989-1006. [PubMed: 26699799]

(50). Glick BS, Pon LA. Isolation of highly purified mitochondria from Saccharomyces cerevisiae. Methods Enzymol. 1995; 260:213-223. [PubMed: 8592446]

(51). Graack HR, Grohmann L, Choli T. Mitochondrial ribosomes of yeast: isolation of individual proteins and N-terminal sequencing. FEBS Lett. 1988; 242(1):4-8. [PubMed: 3060376]

(52). Lowry OH, Rosebrough NJ, Farr AL, Randall RJ. Protein measurement with the Folin phenol reagent. J. Biol. Chem. 1951; 193(1):265-275. [PubMed: 14907713]

(53). Link AJ, LaBaer J. Trichloroacetic acid (TCA) precipitation of proteins. Cold Spring Harb. Protoc. 2011; 2011(8):993-994. [PubMed: 21807853]

(54). Czempiel W, Klose J, Bass R. Mammalian mitochondrial ribosomes: Characterization of ribosomal proteins by two-dimensional gel electrophoresis. FEBS Lett. 1976; 62(3):259-262. [PubMed: 1278367]

(55). Porras-Yakushi TR, Whitelegge JP, Miranda TB, Clarke S. A novel SET domain methyltransferase modifies ribosomal protein Rpl23ab in yeast. J. Biol. Chem. 2005; 280(41): 34590-34598. [PubMed: 16096273]

(56). Kaiser P, Wohlschlegel J. Identification of ubiquitination sites and determination of ubiquitinchain architectures by mass spectrometry. Methods Enzymol. 2005; 399:266-277. [PubMed: 16338362]

(57). Wohlschlegel JA. Identification of SUMO-conjugated proteins and their SUMO attachment sites using proteomic mass spectrometry. Methods Mol. Biol. 2009; 497:33-49. [PubMed: 19107409] 
(58). Kelstrup CD, Young C, Lavallee R, Nielsen ML, Olsen JV. Optimized Fast and Sensitive Acquisition Methods for Shotgun Proteomics on a Quadrupole Orbitrap Mass Spectrometer. J. Proteome Res. 2012; 11(6):3487-3497. [PubMed: 22537090]

(59). Michalski A, Damoc E, Hauschild J-P, Lange O, Wieghaus A, Makarov A, Nagaraj N, Cox J, Mann M, Horning S. Mass spectrometry-based proteomics using Q Exactive, a high-performance benchtop quadrupole Orbitrap mass spectrometer. Mol. Cell. Proteomics. 2011; 10(9) M111.011015.

(60). Cociorva D, Tabb DL, Yates JR. Validation of tandem mass spectrometry database search results using DTASelect. Curr. Protoc. Bioinformatics. 2007 Chapter 13, Unit 13.4.

(61). Tabb DL, McDonald WH, Yates JR. DTASelect and Contrast: tools for assembling and comparing protein identifications from shotgun proteomics. J. Proteome Res. 2002; 1(1):21-26. [PubMed: 12643522]

(62). Xu T, Venable JD, Park SK, Cociorva D, Lu D, Liao L, Wohlschlegel J, Hewel J, Yates JR. ProLuCID, a fast and sensitive tandem mass spectra-based protein identification program. Mol. Cell. Proteomics. 2006; 5:S174.

(63). Elias JE, Gygi SP. Target-decoy search strategy for increased confidence in large-scale protein identifications by mass spectrometry. Nat. Methods. 2007; 4(3):207-214. [PubMed: 17327847]

(64). MacLean B, Tomazela DM, Shulman N, Chambers M, Finney GL, Frewen B, Kern R, Tabb DL, Liebler DC, MacCoss MJ. Skyline: an open source document editor for creating and analyzing targeted proteomics experiments. Bioinformatics. 2010; 26(7):966-968. [PubMed: 20147306]

(65). Kim S, Pevzner PA. MS-GF+ makes progress towards a universal database search tool for proteomics. Nat. Commun. 2014; 5:5277. [PubMed: 25358478]

(66). Käll L, Canterbury JD, Weston J, Noble WS, MacCoss MJ. Semi-supervised learning for peptide identification from shotgun proteomics datasets. Nat. Methods. 2007; 4(11):923-925. [PubMed: 17952086]

(67). Taus T, Köcher T, Pichler P, Paschke C, Schmidt A, Henrich C, Mechtler K. Universal and confident phosphorylation site localization using phosphoRS. J. Proteome Res. 2011; 10(12): 5354-5362. [PubMed: 22073976]

(68). Crooks GE, Hon G, Chandonia J-M, Brenner SE. WebLogo: a sequence logo generator. Genome Res. 2004; 14(6):1188-1190. [PubMed: 15173120]

(69). Kelley LA, Mezulis S, Yates CM, Wass MN, Sternberg MJE. The Phyre2 web portal for protein modeling, prediction and analysis. Nat. Protoc. 2015; 10(6):845-858. [PubMed: 25950237]

(70). Hulsen T, de Vlieg J, Alkema W. BioVenn - a web application for the comparison and visualization of biological lists using area-proportional Venn diagrams. BMC Genomics. 2008; 9(1):488. [PubMed: 18925949]

(71). Consortium TU. UniProt: a hub for protein information. Nucleic Acids Res. 2015; 43(D1):D204D212. [PubMed: 25348405]

(72). Washburn MP, Wolters D, Yates JR. Large-scale analysis of the yeast proteome by multidimensional protein identification technology. Nat. Biotechnol. 2001; 19(3):242-247. [PubMed: 11231557]

(73). Isnard $\mathrm{AD}$, Thomas $\mathrm{D}$, Surdin-Kerjan $\mathrm{Y}$. The study of methionine uptake in Saccharomyces cerevisiae reveals a new family of amino acid permeases. J. Mol. Biol. 1996; 262(4):473-484. [PubMed: 8893857]

(74). Cherest H, Surdin-Kerjan Y. S-adenosyl methionine requiring mutants in Saccharomyces cerevisiae: evidences for the existence of two methionine adenosyl transferases. Mol. Gen. Genet. 1978; 163(2):153-167. [PubMed: 355845]

(75). Sassanfar M, Samson L. Identification and preliminary characterization of an O6-methylguanine DNA repair methyltransferase in the yeast Saccharomyces cerevisiae. J. Biol. Chem. 1990; 265(1):20-25. [PubMed: 2403555]

(76). Taylor GR, Barclay BJ, Storms RK, Friesen JD, Haynes RH. Isolation of the thymidylate synthetase gene (TMP1) by complementation in Saccharomyces cerevisiae. Mol. Cell. Biol. 1982; 2(4):437-442. [PubMed: 6287238] 
(77). Suliman HS, Sawyer GM, Appling DR, Robertus JD. Purification and properties of cobalaminindependent methionine synthase from Candida albicans and Saccharomyces cerevisiae. Arch. Biochem. Biophys. 2005; 441(1):56-63. [PubMed: 16083849]

(78). D'Andrea R, Surdin-Kerjan Y, Pure G, Cherest H. Molecular genetics of met 17 and met 25 mutants of Saccharomyces cerevisiae: intragenic complementation between mutations of a single structural gene. Mol. Gen. Genet. 1987; 207(1):165-170. [PubMed: 3299001]

(79). Thomas D, Becker A, Surdin-Kerjan Y. Reverse methionine biosynthesis from Sadenosylmethionine in eukaryotic cells. J. Biol. Chem. 2000; 275(52):40718-40724. [PubMed: 11013242]

(80). Cherry JM, Hong EL, Amundsen C, Balakrishnan R, Binkley G, Chan ET, Christie KR, Costanzo MC, Dwight SS, Engel SR, et al. Nucleic Acids Res. 2012; 40:D700-705. Database issue. [PubMed: 22110037]

(81). Porras-Yakushi TR, Whitelegge JP, Clarke S. Yeast ribosomal/cytochrome c SET domain methyltransferase subfamily: identification of Rpl23ab methylation sites and recognition motifs. J. Biol. Chem. 2007; 282(17):12368-12376. [PubMed: 17327221]

(82). Webb KJ, Laganowsky A, Whitelegge JP, Clarke SG. Identification of two SET domain proteins required for methylation of lysine residues in yeast ribosomal protein Rpl42ab. J. Biol. Chem. 2008; 283(51):35561-35568. [PubMed: 18957409]

(83). Chern M-K, Chang K-N, Liu L-F, Tam T-CS, Liu Y-C, Liang Y-L, Tam MF. Yeast ribosomal protein L12 is a substrate of protein-arginine methyltransferase 2. J. Biol. Chem. 2002; 277(18): 15345-15353. [PubMed: 11856739]

(84). Webb KJ, Al-Hadid Q, Zurita-Lopez CI, Young BD, Lipson RS, Clarke SG. The ribosomal 11 protuberance in yeast is methylated on a lysine residue catalyzed by a seven-beta-strand methyltransferase. J. Biol. Chem. 2011; 286(21):18405-18413. [PubMed: 21460220]

(85). Young BD, Weiss DI, Zurita-Lopez CI, Webb KJ, Clarke SG, McBride AE. Identification of methylated proteins in the yeast small ribosomal subunit: a role for SPOUT methyltransferases in protein arginine methylation. Biochemistry. 2012; 51(25):5091-5104. [PubMed: 22650761]

(86). Webb KJ, Lipson RS, Al-Hadid Q, Whitelegge JP, Clarke SG. Identification of protein Nterminal methyltransferases in yeast and humans. Biochemistry. 2010; 49(25):5225-5235. [PubMed: 20481588]

(87). Lipson RS, Webb KJ, Clarke SG. Rmt1 catalyzes zinc-finger independent arginine methylation of ribosomal protein Rps2 in Saccharomyces cerevisiae. Biochem. Biophys. Res. Commun. 2010; 391(4):1658-1662. [PubMed: 20035717]

(88). Cavallius J, Zoll W, Chakraburtty K, Merrick WC. Characterization of yeast EF-1a: Nonconservation of post-translational modifications. Biochim. Biophys. Acta - Protein Struct. Mol. Enzymol. 1993; 1163(1):75-80.

(89). Zobel-Thropp P, Yang MC, Machado L, Clarke S. A novel post-translational modification of yeast elongation factor 1A. Methylesterification at the C terminus. J. Biol. Chem. 2000; 275(47): 37150-37158. [PubMed: 10973948]

(90). Jakobsson ME, Davydova E, Małecki J, Moen A, Falnes PØ. Saccharomyces cerevisiae Eukaryotic Elongation Factor 1A (eEF1A) Is Methylated at Lys-390 by a METTL21-Like Methyltransferase. PLoS One. 2015; 10(6):e0131426. [PubMed: 26115316]

(91). Couttas TA, Raftery MJ, Padula MP, Herbert BR, Wilkins MR. Methylation of translationassociated proteins in Saccharomyces cerevisiae: Identification of methylated lysines and their methyltransferases. Proteomics. 2012; 12(7):960-972. [PubMed: 22522802]

(92). Iost I, Dreyfus M, Linder P. Ded1p, a DEAD-box protein required for translation initiation in Saccharomyces cerevisiae, is an RNA helicase. J. Biol. Chem. 1999; 274(25):17677-17683. [PubMed: 10364207]

(93). Erce MA, Abeygunawardena D, Low JKK, Hart-Smith G, Wilkins MR. Interactions affected by arginine methylation in the yeast protein-protein interaction network. Mol. Cell. Proteomics. 2013; 12(11):3184-3198. [PubMed: 23918811]

(94). Garcia BA, Hake SB, Diaz RL, Kauer M, Morris SA, Recht J, Shabanowitz J, Mishra N, Strahl $\mathrm{BD}$, Allis CD, et al. Organismal differences in post-translational modifications in histones $\mathrm{H} 3$ and H4. J. Biol. Chem. 2007; 282(10):7641-7655. [PubMed: 17194708] 
(95). Hasin N, Cusack SA, Ali SS, Fitzpatrick DA, Jones GW. Global transcript and phenotypic analysis of yeast cells expressing Ssa1, Ssa2, Ssa3 or Ssa4 as sole source of cytosolic Hsp70-Ssa chaperone activity. BMC Genomics. 2014; 15(1):194. [PubMed: 24628813]

(96). Haslbeck M, Walke S, Stromer T, Ehrnsperger M, White HE, Chen S, Saibil HR, Buchner J. Hsp26: a temperature-regulated chaperone. EMBO J. 1999; 18(23):6744-6751. [PubMed: 10581247]

(97). Graack HR, Wittmann-Liebold B. Mitochondrial ribosomal proteins (MRPs) of yeast. Biochem. J. 1998; 329:433-448. Pt 3. [PubMed: 9445368]

(98). Mazzoleni M, Figuet S, Martin-Laffon J, Mininno M, Gilgen A, Leroux M, Brugière S, Tardif M, Alban C, Ravanel S. Dual-targeting of the protein methyltransferase PrmA contributes to both chloroplastic and mitochondrial ribosomal protein L11 methylation in Arabidopsis. Plant Cell Physiol. 2015; 569:1697-1710. [PubMed: 26116422]

(99). Rinnerthaler M, Jarolim S, Heeren G, Palle E, Perju S, Klinger H, Bogengruber E, Madeo F, Braun RJ, Breitenbach-Koller L, et al. MMI1 (YKL056c, TMA19), the yeast orthologue of the translationally controlled tumor protein (TCTP) has apoptotic functions and interacts with both microtubules and mitochondria. Biochim. Biophys. Acta. 2006; 1757(5-6):631-638. [PubMed: 16806052]

(100). Gao W-W, Xiao R-Q, Peng B-L, Xu H-T, Shen H-F, Huang M-F, Shi T-T, Yi J, Zhang W-J, Wu $\mathrm{X}-\mathrm{N}$, et al. Arginine methylation of HSP70 regulates retinoid acid-mediated RAR $\beta 2$ gene activation. Proc. Natl. Acad. Sci. 2015; 112(26):E3327-3336. [PubMed: 26080448]

(101). Al-Hadid Q, Roy K, Munroe W, Dzialo MC, Chanfreau GF, Clarke SG. Histidine methylation of yeast ribosomal protein Rpl3p is required for proper 60S subunit assembly. Mol. Cell. Biol. 2014; 34(15):2903-2916. [PubMed: 24865971]

(102). Klotz AV, Thomas BA, Glazer AN, Blacher RW. Detection of methylated asparagine and glutamine residues in polypeptides. Anal. Biochem. 1990; 186(1):95-100. [PubMed: 2356973]

(103). Sprung R, Chen Y, Zhang K, Cheng D, Zhang T, Peng J, Zhao Y. Identification and validation of eukaryotic aspartate and glutamate methylation in proteins. J. Proteome Res. 2008; 7(3):10011006. [PubMed: 18220335]

(104). Low JKK, Wilkins MR. Protein arginine methylation in Saccharomyces cerevisiae. FEBS J. 2012; 279(24):4423-4443. [PubMed: 23094907]

(105). Henry MF, Silver PA. A novel methyltransferase (Hmt1p) modifies poly(A)+-RNA-binding proteins. Mol. Cell. Biol. 1996; 16(7):3668-3678. [PubMed: 8668183]

(106). Low JKK, Hart-Smith G, Erce MA, Wilkins MR. The Saccharomyces cerevisiae poly(A)binding protein is subject to multiple post-translational modifications, including the methylation of glutamic acid. Biochem. Biophys. Res. Commun. 2014; 443(2):543-548. [PubMed: 24326073]

(107). Yi X, Weis RM. The receptor docking segment and S-adenosyl-L-homocysteine bind independently to the methyltransferase of bacterial chemotaxis. Biochim. Biophys. Acta - Protein Struct. Mol. Enzymol. 2002; 1596(1):28-35.

(108). Wang X, Mann CJ, Bai Y, Ni L, Weiner H. Molecular cloning, characterization, and potential roles of cytosolic and mitochondrial aldehyde dehydrogenases in ethanol metabolism in Saccharomyces cerevisiae. J. Bacteriol. 1998; 180(4):822-830. [PubMed: 9473035]

(109). Miran SG, Lawson JE, Reed LJ. Characterization of PDH beta 1, the structural gene for the pyruvate dehydrogenase beta subunit from Saccharomyces cerevisiae. Proc. Natl. Acad. Sci. 1993; 90(4):1252-1256. [PubMed: 8433986]

(110). Chen XJ, Wang X, Kaufman BA, Butow RA. Aconitase couples metabolic regulation to mitochondrial DNA maintenance. Science. 2005; 307(5710):714-717. [PubMed: 15692048]

(111). Kaufman BA, Newman SM, Hallberg RL, Slaughter CA, Perlman PS, Butow RA. In organello formaldehyde crosslinking of proteins to mtDNA: identification of bifunctional proteins. Proc. Natl. Acad. Sci. 2000; 97(14):7772-7777. [PubMed: 10869431]

(112). Gangloff SP, Marguet D, Lauquin GJ. Molecular cloning of the yeast mitochondrial aconitase gene (ACO1) and evidence of a synergistic regulation of expression by glucose plus glutamate. Mol. Cell. Biol. 1990; 10(7):3551-3561. [PubMed: 1972545] 
(113). Chen XJ, Wang X, Butow RA. Yeast aconitase binds and provides metabolically coupled protection to mitochondrial DNA. Proc. Natl. Acad. Sci. 2007; 104(34):13738-13743. [PubMed: 17698960]

(114). Holt LJ, Tuch BB, Villén J, Johnson AD, Gygi SP, Morgan DO. Global analysis of Cdk1 substrate phosphorylation sites provides insights into evolution. Science. 2009; 325(5948):16821686. [PubMed: 19779198]

(115). Reinders J, Wagner K, Zahedi RP, Stojanovski D, Eyrich B, van der Laan M, Rehling P, Sickmann A, Pfanner N, Meisinger C. Profiling phosphoproteins of yeast mitochondria reveals a role of phosphorylation in assembly of the ATP synthase. Mol. Cell. Proteomics. 2007; 6(11): 1896-1906. [PubMed: 17761666]

(116). Li X, Gerber SA, Rudner AD, Beausoleil SA, Haas W, Villén J, Elias JE, Gygi SP. Large-scale phosphorylation analysis of alpha-factor-arrested Saccharomyces cerevisiae. J. Proteome Res. 2007; 6(3):1190-1197. [PubMed: 17330950]

(117). Graack HR, Grohmann L, Kitakawa M, Goldschmidt-Reisin S. Gene MRP-L4, encoding mitochondrial ribosomal protein $\mathrm{YmL} 4$, is indispensable for proper non-respiratory cell functions in yeast. Gene. 1995; 152(1):107-112. [PubMed: 7828914]

(118). Gan X, Kitakawa M, Yoshino K-I, Oshiro N, Yonezawa K, Isono K. Tag-mediated isolation of yeast mitochondrial ribosome and mass spectrometric identification of its new components. Eur. J. Biochem. 2002; 269(21):5203-5214. [PubMed: 12392552]

(119). Sato H, Miyakawa I. A $22 \mathrm{kDa}$ protein specific for yeast mitochondrial nucleoids is an unidentified putative ribosomal protein encoded in open reading frame YGL068W. Protoplasma. 2004; 223(2-4):175-182. [PubMed: 15221522]

(120). Stevenson LF, Kennedy BK, Harlow E. A large-scale overexpression screen in Saccharomyces cerevisiae identifies previously uncharacterized cell cycle genes. Proc. Natl. Acad. Sci. 2001; 98(7):3946-3951. [PubMed: 11274415]

(121). Ladror DT, Frey BL, Scalf M, Levenstein ME, Artymiuk JM, Smith LM. Methylation of yeast ribosomal protein S2 is elevated during stationary phase growth conditions. Biochem. Biophys. Res. Commun. 2014; 445(3):535-541. [PubMed: 24486316]

(122). Lawson JE, Niu XD, Reed LJ. Functional analysis of the domains of dihydrolipoamide acetyltransferase from Saccharomyces cerevisiae. Biochemistry. 1991; 30(47):11249-11254. [PubMed: 1958662]

(123). Kehrein K, Schilling R, Möller-Hergt BV, Wurm CA, Jakobs S, Lamkemeyer T, Langer T, Ott M. Organization of Mitochondrial Gene Expression in Two Distinct Ribosome-Containing Assemblies. Cell Rep. 2015; 10(6):843-853.

(124). Baumann F, Milisav I, Neupert W, Herrmann JM. Ecm10, a novel hsp70 homolog in the mitochondrial matrix of the yeast Saccharomyces cerevisiae. FEBS Lett. 2000; 487(2):307-312. [PubMed: 11150530]

(125). Reinders J, Zahedi RP, Pfanner N, Meisinger C, Sickmann A. Toward the complete yeast mitochondrial proteome: multidimensional separation techniques for mitochondrial proteomics. J. Proteome Res. 2006; 5(7):1543-1554. [PubMed: 16823961]

(126). Sakasegawa Y, Hachiya NS, Tsukita S, Kaneko K. Ecm10p localizes in yeast mitochondrial nucleoids and its overexpression induces extensive mitochondrial DNA aggregations. Biochem. Biophys. Res. Commun. 2003; 309(1):217-221. [PubMed: 12943685]

(127). Cloutier P, Lavallée-Adam M, Faubert D, Blanchette M, Coulombe B. A newly uncovered group of distantly related lysine methyltransferases preferentially interact with molecular chaperones to regulate their activity. PLoS Genet. 2013; 9(1):e1003210. [PubMed: 23349634]

(128). Kernstock S, Davydova E, Jakobsson M, Moen A, Pettersen S, Mælandsmo GM, Egge-Jacobsen $\mathrm{W}$, Falnes PØ. Lysine methylation of VCP by a member of a novel human protein methyltransferase family. Nat. Commun. 2012; 3:1038. [PubMed: 22948820]

(129). Jakobsson ME, Moen A, Bousset L, Egge-Jacobsen W, Kernstock S, Melki R, Falnes PØ. Identification and characterization of a novel human methyltransferase modulating Hsp70 protein function through lysine methylation. J. Biol. Chem. 2013; 288(39):27752-27763. [PubMed: 23921388] 
(130). Cho H-S, Shimazu T, Toyokawa G, Daigo Y, Maehara Y, Hayami S, Ito A, Masuda K, Ikawa N, Field HI, et al. Enhanced HSP70 lysine methylation promotes proliferation of cancer cells through activation of Aurora kinase B. Nat. Commun. 2012; 3:1072. [PubMed: 22990868]

(131). Cloutier P, Coulombe B. Regulation of molecular chaperones through post-translational modifications: decrypting the chaperone code. Biochim. Biophys. Acta. 2013; 1829(5):443-454. [PubMed: 23459247] 


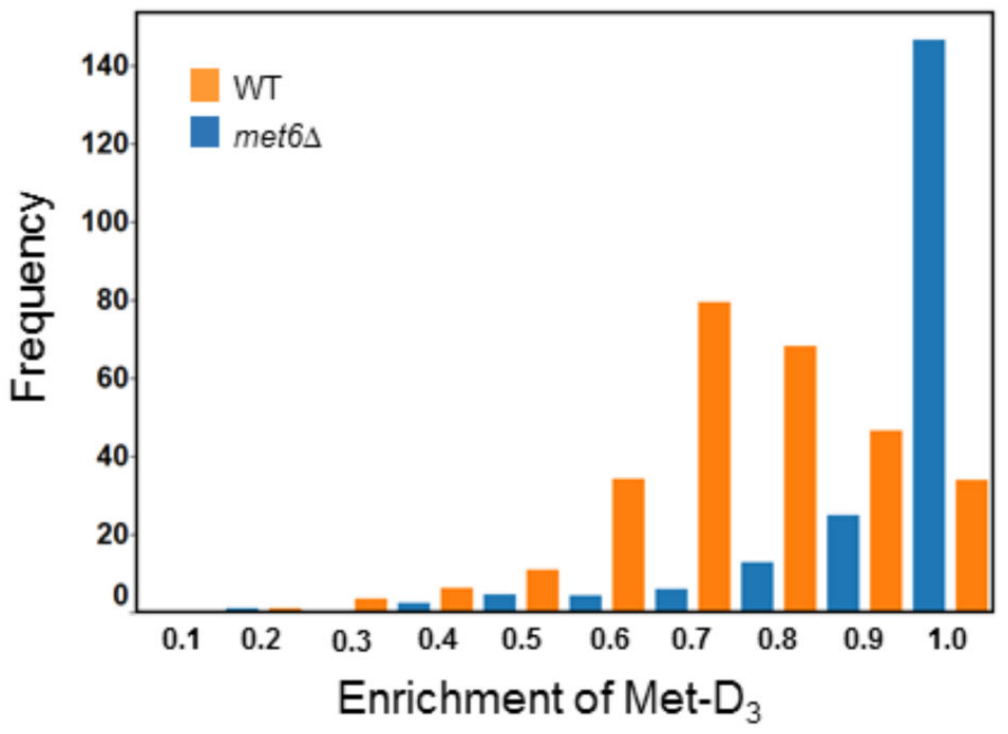

Figure 1.

Improved enrichment of the deuterated methionine label into proteins of $S$. cerevisiae strains with a deletion in the MET6 gene encoding the cobalamin-independent methionine synthase. As described in "Materials and Methods", wild type (WT) and met6 $\Delta$ strains were heavylabeled, mitochondrial ribosomal proteins were isolated, digested with trypsin/Lys-C and analyzed by LC-MS/MS. For each peptide identified, the ratio of the areas of the extracted ion chromatograms for each labeled and unlabeled peptide pair was calculated to obtain a fractional enrichment of L- $\left[\right.$ methyl- $\left.\mathrm{D}_{3}\right]$-methionine $\left(\right.$ Met- $\left.\mathrm{D}_{3}\right)$. 
A.
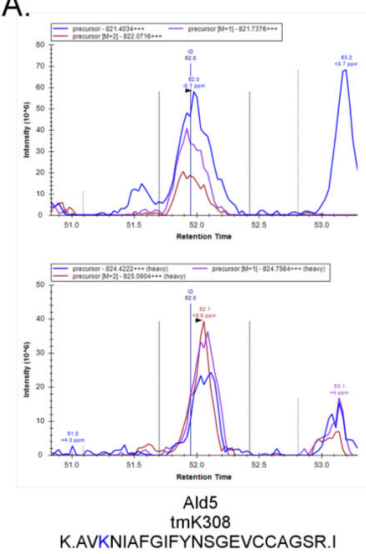

C.
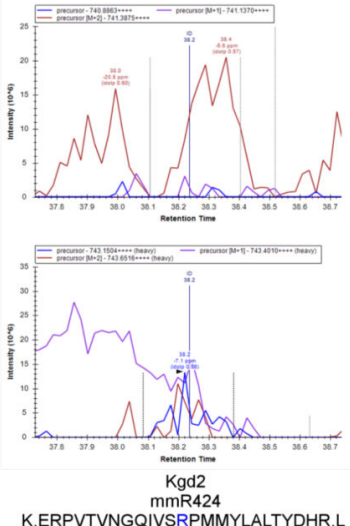

B.

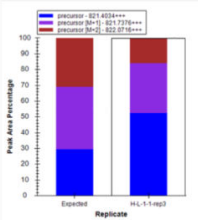

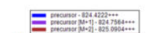

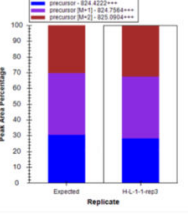

D.
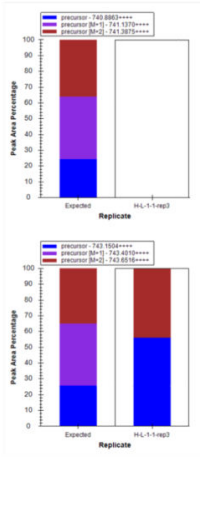

Figure 2.

Examples of good and poor methylated peptide identifications in MS1 ion chromatograms. (A) Extracted precursor ion chromatograms for light (top) and heavy (bottom) peptides containing a candidate trimethyl K308 on Ald5. The zero, +1 and +2 isotopes are shown in blue, magenta, and red, respectively. The methylated residue is highlighted in blue in the peptide sequence. (B) Corresponding peak areas of both experimental and theoretical precursor ions for the heavy and light peptide containing this modification. (C, D) Extracted precursor ion chromatograms for light and heavy peptides containing an identified, but unlikely monomethyl R424 on $\mathrm{Kgd} 2$, analyzed as in panels A and B above. These chromatograms are from the mitochondrial fraction. 


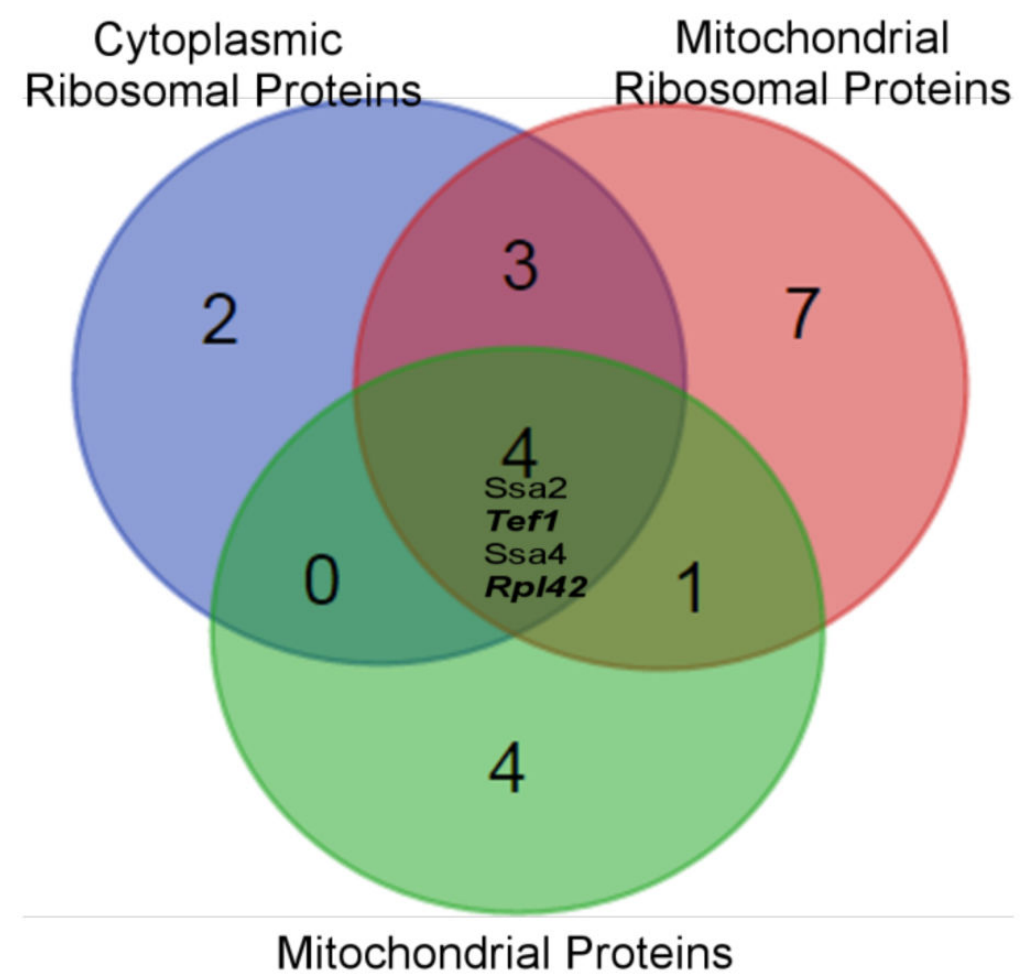

Figure 3.

Overlap of methylated proteins between cytoplasmic ribosomal proteins (blue), mitochondrial ribosomal proteins (pink), and mitochondrial protein fractions (green). The four methylated proteins found in all three protein fractions are listed. Known methylated proteins are bolded and italicized. 
A.
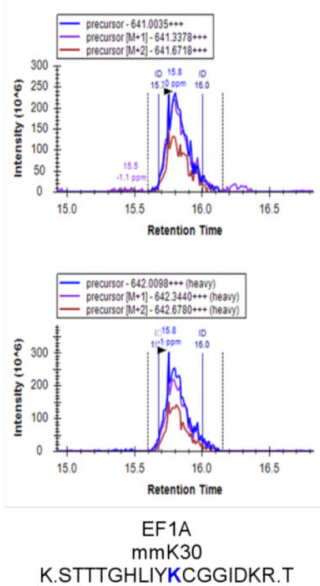

B.
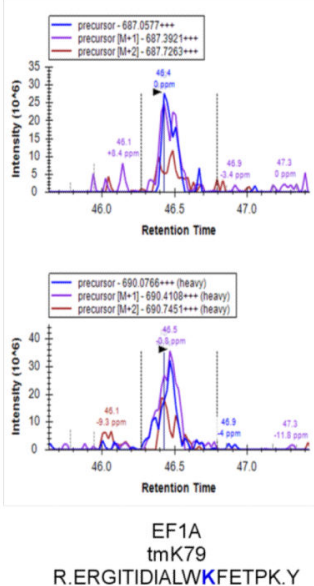

C.
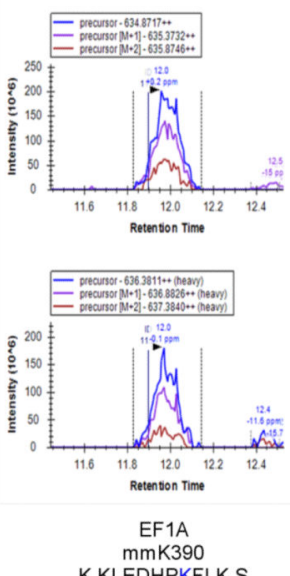

Figure 4.

Confirmation of known methylation sites on EF1A. Extracted precursor ion chromatograms for light (top) and heavy (bottom) peptides containing (A) monomethyl K30, (B) trimethyl $\mathrm{K} 79$, and (C) monomethyl K390. The zero, +1 and +2 isotopes are shown in blue, magenta, and red, respectively. The methylated residue is highlighted in blue in the peptide sequence. Chromatograms are representative of three replicates from the cytoplasmic ribosomal protein fraction. 
A.

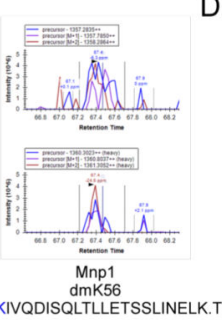

B.
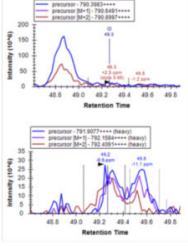

$$
\begin{gathered}
\text { Mrpl4 } \\
\mathrm{mmR204}
\end{gathered}
$$

K.KFLDTLANDYFLNKDIPDDEVASMLTR.

C.
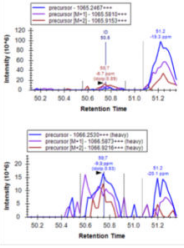

Mrpl40
D.

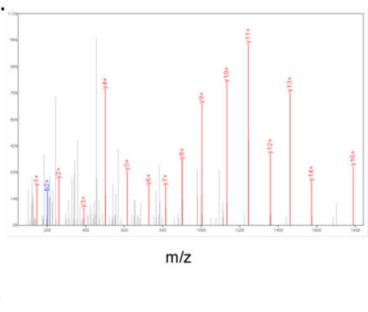

E.

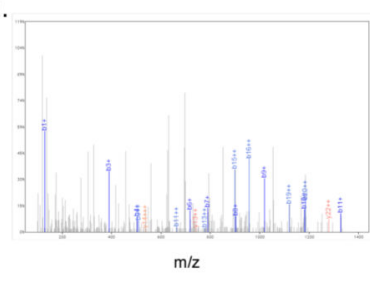

F.
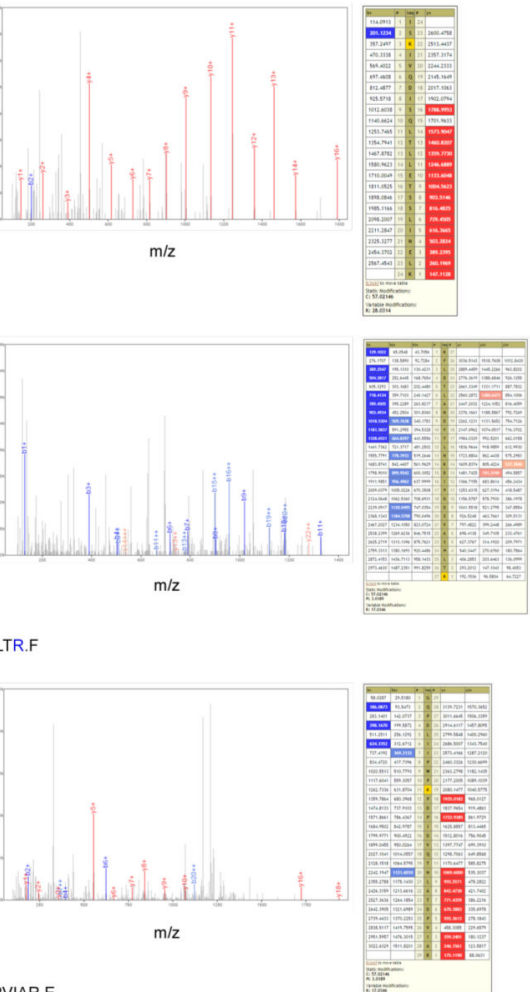

Figure 5.

Novel methylated peptides found in mitochondrial ribosomal protein fraction. Extracted precursor ion chromatograms for light (top) and heavy (bottom) peptides containing (A) dimethyl K56 on Mnp1, (B) monomethyl R204 on Mrpl4, and (C) monomethyl K186 on Mrp140. The zero, +1 and +2 isotopes are shown in blue, magenta, and red, respectively. The methylated residue is highlighted in blue in the peptide sequence. Fragmentation patterns of product ions for (D) Mnp1, (E) Mrpl4, and (F) Mrpl40 methyl peptides. Methylated residue is highlighted in yellow in the peptide sequence. 
A.
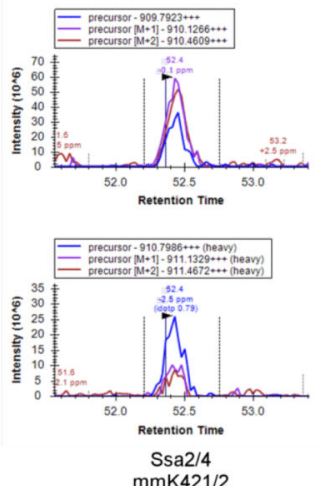

KKSEVFSTYADNOPGVLIQVFEGER A
B.
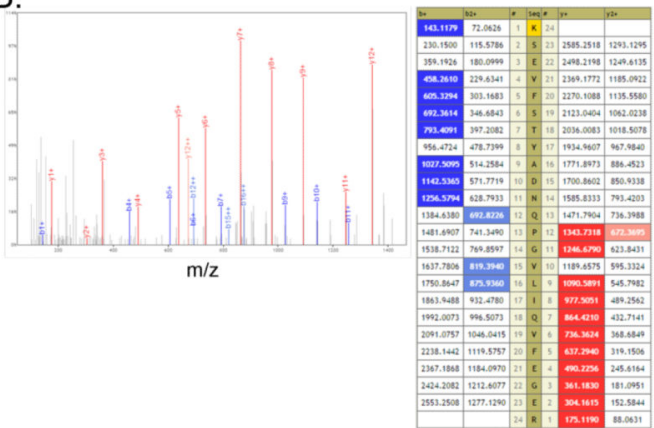

Figure 6.

Novel methylation of Ssa2/4 in all three protein fractions. Extracted precursor ion chromatograms for light (top) and heavy (bottom) peptides containing (A) monomethyl $\mathrm{K} 421 / 2$ on Ssa2/4. The zero, +1 and +2 isotopes are shown in blue, magenta, and red, respectively. The methylated residue is highlighted in blue in the peptide sequence. (B) Fragmentation patterns of product ions for Ssa2/4 methyl peptide. Methylated residue is highlighted in yellow in the peptide sequence. Chromatograms and fragmentations are representative of three replicates from the three protein fractions. 


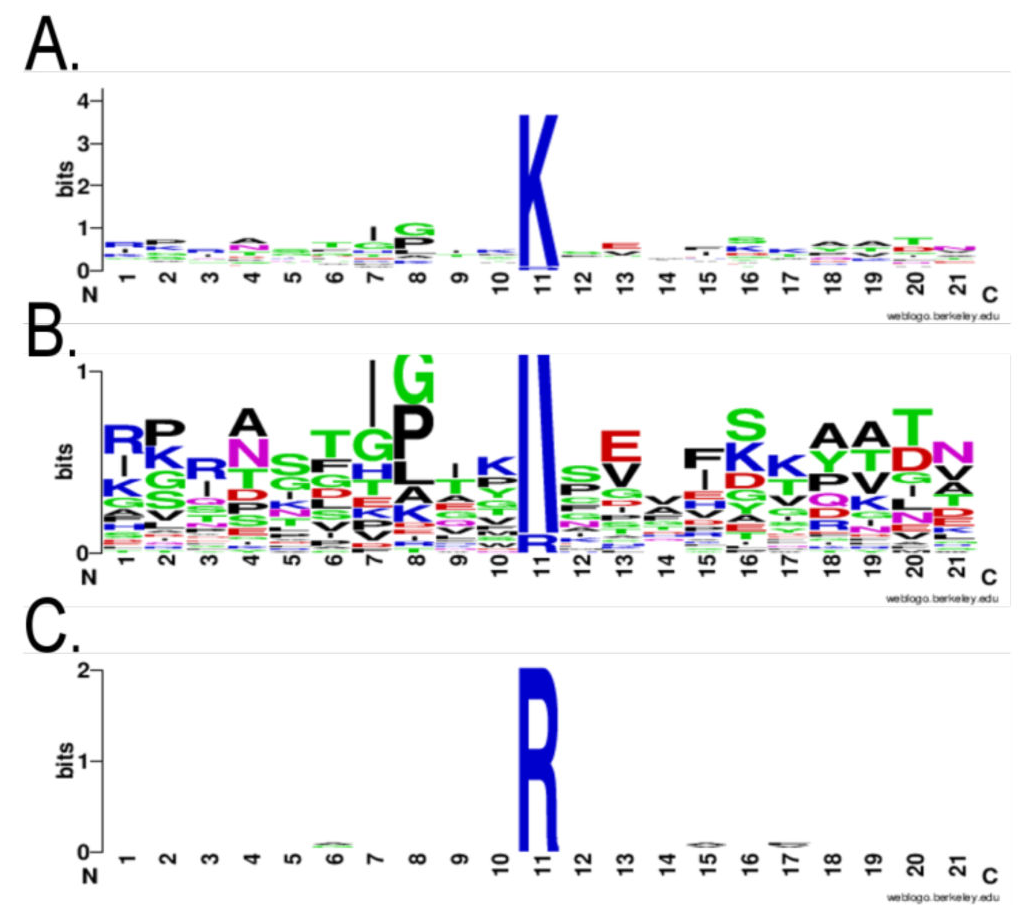

Figure 7.

Sequence similarity between identified methylated residues. (A) Logo of sequence of amino acids 10 residues before and after identified methylated lysine. (B) Zoomed in view of logo, looking at the first bit of identified methylated lysine sequences. (C) Logo of sequence of amino acids 10 residues before and after identified methylated arginine. 


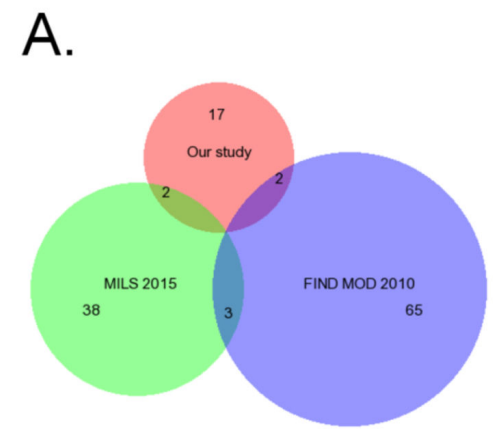

B.

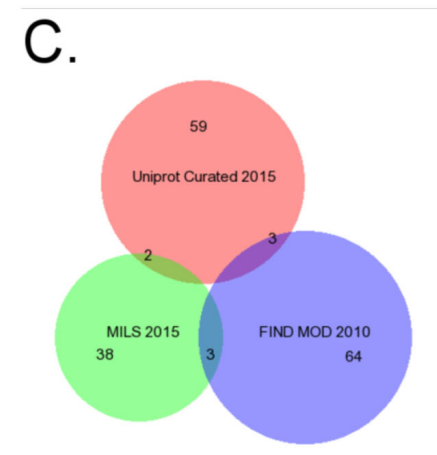

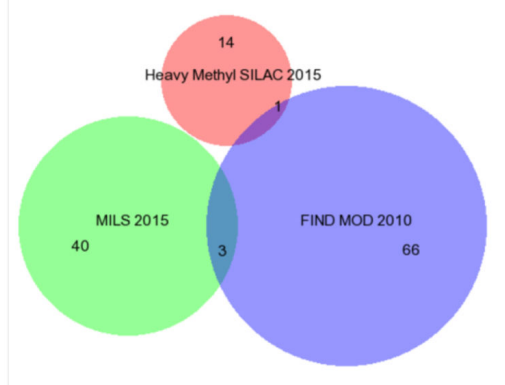

D.

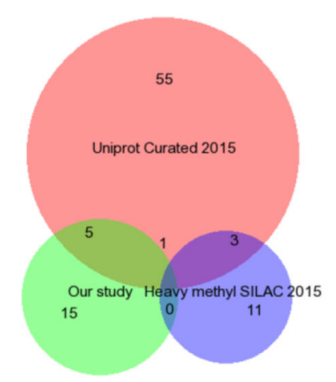

Figure 8.

Overlap of methylated proteins identified from the literature and curated from Uniprot. (A) Comparison between "Our study" (red), "MILS 2015" (green), and "FIND MOD 2010" (blue). (B) Comparison between known studies "Heavy methyl SILAC 2015" (red), "MILS 2015" (green), and "FIND MOD 2010" (blue). (C) Comparison to "Uniprot Curated 2015", "MILS 2015" (green), and "FIND MOD 2010" (blue). (D) Comparison to "Uniprot Curated 2015", "Our study" (green), and "Heavy methyl SILAC 2015" (blue). "Our study" was candidate proteins identified in this work. "FIND MOD 2010" proteins are from Pang et al., 2010, "MILS 2015" proteins are from Wang et al., 2015, "Heavy methyl SILAC 2015" proteins are from Plank et al., 2015, and "Uniprot Curated 2015" proteins were manually curated from Uniprot in March 2015. 
Table 1

Validating Methods for Cytoplasmic Ribosomal Fraction

\begin{tabular}{|c|c|c|c|c|c|}
\hline \multicolumn{6}{|c|}{ Novel Methylation Sites Found } \\
\hline Protein & Site $^{a}$ & Sequence $^{b}$ & $\begin{array}{l}\text { Percolator } \\
\text { q-value }\end{array}$ & $\begin{array}{l}\text { Methyl Site } \\
\text { Probability }^{c}\end{array}$ & $\begin{array}{l}\text { Localizat } \\
\text { ion } d\end{array}$ \\
\hline Rpl23ab & $\begin{array}{l}\operatorname{tmK} 106 \\
\text { mmK110 }\end{array}$ & $\begin{array}{l}\text { R.DGVFLYFEDNAGVIANPKGEMK } \\
\text { GSAITGPVGK.E }\end{array}$ & - & - & $\begin{array}{l}\text { Cytoplas } \\
\mathrm{m}\end{array}$ \\
\hline Rp123ab & $\begin{array}{l}\operatorname{dmK} 110 \\
\operatorname{dmK} 120\end{array}$ & 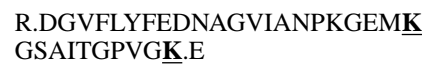 & - & - & $\begin{array}{l}\text { Cytoplas } \\
\mathrm{m}\end{array}$ \\
\hline $\begin{array}{l}\text { Histone } \\
\mathrm{H} 3\end{array}$ & $\mathrm{mmK} 38$ & K.SAPSTGGVK $\underline{\text { PPHR.Y }}$ & - & - & Nucleus \\
\hline eEF1A & $\begin{array}{l}\operatorname{mmK} 30 \\
\mathrm{mmK} 35\end{array}$ & K.STTTGHLIY $\underline{\text { KCGGIDK} . R ~}$ & - & - & $\begin{array}{l}\text { Cytoplas } \\
\mathrm{m}\end{array}$ \\
\hline $\mathrm{Ssa} / 4$ & $\begin{array}{l}\operatorname{mmK} 421 \\
/ 422\end{array}$ & $\begin{array}{l}\text { K.KSEVFSTYADNQPGVLIQVFEGE } \\
\text { R.T }\end{array}$ & - & - & $\begin{array}{l}\text { Cytoplas } \\
\text { m, } \\
\text { Mitochon } \\
\text { dria, } \\
\text { Nucleus, } \\
\text { Vacuole }\end{array}$ \\
\hline Hsp26 & dmR89 & $\begin{array}{l}\text { K.EVARPNNYAGALYDPRDETLDD } \\
\text { WFDNDLSLFPSGFGFP } \underline{\mathbf{R}} . \mathrm{S}\end{array}$ & 0 & 0 & $\begin{array}{l}\text { Cytoplas } \\
\text { m, } \\
\text { Nucleus }\end{array}$ \\
\hline \multicolumn{6}{|c|}{ Known Ribosomal Protein Methylation Sites Found } \\
\hline Protein & Site & Sequence & $\begin{array}{l}\text { Percolator } \\
\text { q-value }\end{array}$ & $\begin{array}{l}\text { Methyl Site } \\
\text { Probability }\end{array}$ & $\begin{array}{l}\text { Localizat } \\
\text { ion }\end{array}$ \\
\hline Rpl12ab & mmR67 & $\begin{array}{l}\text { K.IQNRQAAASVVPSASSLVITALK. } \\
\text { E } \\
\text { K.IQNRQAAASVVPSASSLVITALK } \\
\text { EPPR.D }\end{array}$ & $\begin{array}{l}0 \\
0\end{array}$ & $\begin{array}{l}100 \\
100\end{array}$ & $\begin{array}{l}\text { Cytoplas } \\
\mathrm{m}\end{array}$ \\
\hline Rpl23ab & $\begin{array}{l}\text { dmK106, } \\
\text { dmK110 }\end{array}$ & 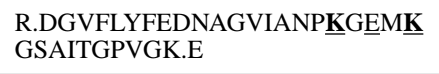 & 0.00134386 & $\begin{array}{l}\text { K106: } 50.11 \\
\text { K110: } 99.77\end{array}$ & $\begin{array}{l}\text { Cytoplas } \\
\mathrm{m}\end{array}$ \\
\hline Rp142ab & $\mathrm{mmK} 55$ & 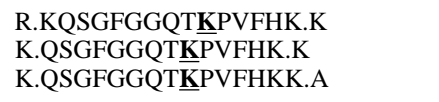 & $\begin{array}{l}0 \\
0 \\
5.34 \times 10^{-5}\end{array}$ & $\begin{array}{l}100 \\
100 \\
100\end{array}$ & $\begin{array}{l}\text { Cytoplas } \\
\mathrm{m}\end{array}$ \\
\hline \multicolumn{6}{|c|}{ Known Ribosome-Associated Methylation Sites Found } \\
\hline Protein & Site & Sequence & $\begin{array}{l}\text { Percolator } \\
\text { q-value }\end{array}$ & $\begin{array}{l}\text { Methyl Site } \\
\text { Probability }\end{array}$ & $\begin{array}{l}\text { Localizat } \\
\text { ion }\end{array}$ \\
\hline eEF1A & $\mathrm{mmK} 30$ & $\begin{array}{l}\text { K.STTTGHLIYKCGGIDK.R } \\
\text { K.STTTGHLIY } \underline{\mathbf{K} C G G I D K R . T}\end{array}$ & $\begin{array}{l}0 \\
0\end{array}$ & $\begin{array}{l}100 \\
100\end{array}$ & $\begin{array}{l}\text { Cytoplas } \\
\mathrm{m}\end{array}$ \\
\hline eEF1A & $\operatorname{tmK} 79$ & 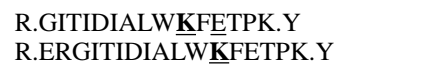 & $\begin{array}{l}0 \\
-\end{array}$ & $\begin{array}{l}100 \\
-\end{array}$ & $\begin{array}{l}\text { Cytoplas } \\
\mathrm{m}\end{array}$ \\
\hline eEF1A & $\operatorname{mmK} 390$ & K.KLEDHPKFLK.S & - & - & $\begin{array}{l}\text { Cytoplas } \\
\mathrm{m}\end{array}$ \\
\hline Ded1 & dmR51 & $\begin{array}{l}\text { R.NNSSNYNNNNGGYNGGRGGGS } \\
\text { FFSNNR.R }\end{array}$ & 0 & 100 & $\begin{array}{l}\text { Cytoplas } \\
\text { m, } \\
\text { Nucleus }\end{array}$ \\
\hline $\begin{array}{l}\text { Histone } \\
\mathrm{H} 3\end{array}$ & dmK37 & 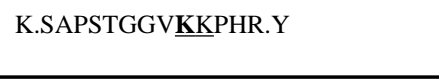 & 0 & 99.71 & Nucleus \\
\hline \multicolumn{6}{|c|}{ Known Ribosomal Protein Methylation Sites Missed } \\
\hline Protein & Site & Potential Reason & & & $\begin{array}{l}\text { Localizat } \\
\text { ion }\end{array}$ \\
\hline
\end{tabular}

J Proteome Res. Author manuscript; available in PMC 2017 December 02. 


\begin{tabular}{|c|c|c|c|c|c|}
\hline \multicolumn{6}{|c|}{ Novel Methylation Sites Found } \\
\hline Protein & Site $^{a}$ & Sequence $^{b}$ & $\begin{array}{l}\text { Percolator } \\
\text { q-value }\end{array}$ & $\begin{array}{l}\text { Methyl Site } \\
\text { Probability }\end{array}$ & $\begin{array}{l}\text { Localizat } \\
\text { ion } d\end{array}$ \\
\hline Rpl12ab & $\operatorname{tmK} 3$ & \multicolumn{3}{|l|}{ Presence of dimethyl proline in position 1} & $\begin{array}{l}\text { Cytoplas } \\
\mathrm{m}\end{array}$ \\
\hline Rpl42ab & $\mathrm{mmK} 40$ & \multicolumn{3}{|l|}{ Unclear } & $\begin{array}{l}\text { Cytoplas } \\
\mathrm{m}\end{array}$ \\
\hline Rpl1 & $\mathrm{mmK} 46$ & \multicolumn{3}{|l|}{ Unclear } & $\begin{array}{l}\text { Cytoplas } \\
\mathrm{m}\end{array}$ \\
\hline Rps2 & $\begin{array}{l}\mathrm{mm} \text { and } \\
\mathrm{dmR} 11\end{array}$ & \multicolumn{3}{|l|}{ Substoichiometric } & $\begin{array}{l}\text { Cytoplas } \\
\mathrm{m}\end{array}$ \\
\hline Rps3 & $\mathrm{mmR} 145$ & \multicolumn{3}{|l|}{ Unclear } & $\begin{array}{l}\text { Cytoplas } \\
\mathrm{m}\end{array}$ \\
\hline
\end{tabular}

${ }^{a}$ Methylated residues are abbreviated as follows: mm- monomethyl, dm- dimethyl, tm- trimethyl.

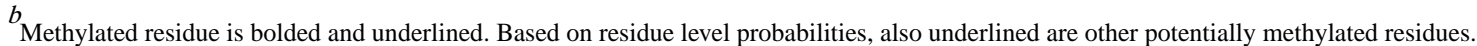

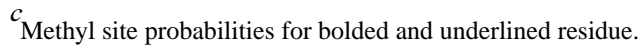

${ }^{d}$ Localization determined from Saccharomyces Genome Database 80 . 
Table 2

Methylated sites found in the mitochondrial ribosomal fraction

\begin{tabular}{|c|c|c|c|c|c|}
\hline \multicolumn{6}{|c|}{ Novel Mitochondrial Ribosomal Methylation Sites Found } \\
\hline Protein & Site $^{a}$ & Sequence $^{b}$ & $\begin{array}{l}\text { Percolator } \\
\text { q-value }\end{array}$ & $\begin{array}{l}\text { Methyl Site } \\
\text { Probability }\end{array}$ & $\begin{array}{l}\text { Localizat } \\
\text { ion } d\end{array}$ \\
\hline Mnp1 & $\mathrm{dmK} 56$ & $\begin{array}{l}\text { K.ISKIVQDISQLTLLETSSLINELK. } \\
\text { T }\end{array}$ & - & - & $\begin{array}{l}\text { Mitochon } \\
\text { dria }\end{array}$ \\
\hline Mrpl4 & $\mathrm{mmR} 204$ & $\begin{array}{l}\text { K.KFLDTLANDYFLNKDIPDDEVAS } \\
\text { MLTR.F }\end{array}$ & - & - & $\begin{array}{l}\text { Mitochon } \\
\text { dria }\end{array}$ \\
\hline Mrpl40 & $\mathrm{mmK} 186$ & $\begin{array}{l}\text { K.GQPDLIIPWPKPDPIDVQTNLAT } \\
\text { DPVIAR.E }\end{array}$ & - & - & $\begin{array}{l}\text { Mitochon } \\
\text { dria }\end{array}$ \\
\hline \multicolumn{6}{|c|}{ Novel Mitochondrial Ribosome-Associated Methylation Sites Found } \\
\hline Protein & Site & Sequence & $\begin{array}{l}\text { Percolator } \\
\text { q-value }\end{array}$ & $\begin{array}{l}\text { Methyl Site } \\
\text { Probability }\end{array}$ & $\begin{array}{l}\text { Localizat } \\
\text { ion }\end{array}$ \\
\hline Lat1 & $\mathrm{mmR} 260$ & $\begin{array}{l}\text { K.QSSQTSGAAAATPAAATSSTTA } \\
\text { GSAPSPSSTASYEDVPISTM‥S }\end{array}$ & - & - & $\begin{array}{l}\text { Mitochon } \\
\text { dria }\end{array}$ \\
\hline Lat1 & $\mathrm{dmK} 340$ & $\begin{array}{l}\text { K.FKNVDVVSVAVATPTGLLTPIVK. } \\
\mathrm{N}\end{array}$ & 0 & 50 & $\begin{array}{l}\text { Mitochon } \\
\text { dria }\end{array}$ \\
\hline Pdb1 & mmR55 & $\begin{array}{l}\text { R.EALNSAMAEELDRDDDVFLIGE } \\
\text { EVAQYNGAYK.V }\end{array}$ & 0 & 0 & $\begin{array}{l}\text { Mitochon } \\
\text { dria }\end{array}$ \\
\hline Ecm10 & $\mathrm{mmK} 558$ & $\begin{array}{l}\text { R.NAIETANKADQLANDTENSIKEF } \\
\text { EGK.L }\end{array}$ & 0 & 99.99 & $\begin{array}{l}\text { Mitochon } \\
\text { dria }\end{array}$ \\
\hline \multicolumn{6}{|c|}{ Novel Methylation Sites Found } \\
\hline Protein & Site & Sequence & $\begin{array}{l}\text { Percolator } \\
\text { q-value }\end{array}$ & $\begin{array}{l}\text { Methyl Site } \\
\text { Probability }\end{array}$ & $\begin{array}{l}\text { Localizat } \\
\text { ion }\end{array}$ \\
\hline Pst2 & $\mathrm{mmK} 144$ & $\begin{array}{l}\text { K.VAGCFVSTGTGGGNEATIMNSL } \\
\text { STLAHHGIIFVPLGYK. } . \mathbf{N}\end{array}$ & 0 & 0 & $\begin{array}{l}\text { Cytoplas } \\
\text { m, } \\
\text { Mitochon } \\
\text { dria }\end{array}$ \\
\hline $\mathrm{Ssa} 2 / 4$ & $\operatorname{mmK}_{/ 422}$ & $\begin{array}{l}\text { K.KSSEVFSTYADNQPGVLIQVFEGE } \\
\text { R.T }\end{array}$ & 0 & 0.36 & $\begin{array}{l}\text { Cytoplas } \\
\text { m, } \\
\text { Mitochon } \\
\text { dria, } \\
\text { Nucleus, } \\
\text { Vacuole }\end{array}$ \\
\hline Rps2 & $\mathrm{mmK} 49$ & K.AGKITTIEEIFLHSLPVK.E & 0 & 100 & $\begin{array}{l}\text { Cytoplas } \\
\mathrm{m}\end{array}$ \\
\hline Rp123ab & $\begin{array}{l}\operatorname{tmK} 106 \\
\operatorname{mmK} 110\end{array}$ & $\begin{array}{l}\text { R.DGVFLYFEDNAGVIANPKGEM트 } \\
\text { GSAITGPVGK.E }\end{array}$ & - & - & $\begin{array}{l}\text { Cytoplas } \\
\mathrm{m}\end{array}$ \\
\hline Rp123ab & $\begin{array}{l}\operatorname{mmK} 106 \\
, \operatorname{tmK} 110\end{array}$ & $\begin{array}{l}\text { R.DGVFLYFEDNAGVIANPKGEM } \underline{\mathbf{K}} \\
\text { GSAITGPVGK.E }\end{array}$ & - & - & $\begin{array}{l}\text { Cytoplas } \\
\mathrm{m}\end{array}$ \\
\hline $\begin{array}{l}\text { Histone } \\
\mathrm{H} 3\end{array}$ & $\mathrm{mmK} 38$ & K.SAPSTGGV $\underline{K K} P H R . Y$ & 0 & 0.34 & Nucleus \\
\hline \multicolumn{6}{|c|}{ Known Methylation Sites Found } \\
\hline Protein & Site & Sequence & $\begin{array}{l}\text { Percolator } \\
\text { q-value }\end{array}$ & $\begin{array}{l}\text { Methyl Site } \\
\text { Probability }\end{array}$ & $\begin{array}{l}\text { Localizat } \\
\text { ion }\end{array}$ \\
\hline Rp123ab & $\begin{array}{l}\text { dmK106, } \\
\text { dmK110 }\end{array}$ & $\begin{array}{l}\text { R.RRDGVFLYFEDNAGVIANPKGE } \\
\text { MKGSAITGPVGK.E }\end{array}$ & 0.001962164 & - & $\begin{array}{l}\text { Cytoplas } \\
\mathrm{m}\end{array}$ \\
\hline Rp142ab & mmK55 & $\begin{array}{l}\text { K.QSGFGGQTKKPVFHK.K } \\
\text { R.KQSGFGGQTEPVFH.K }\end{array}$ & $\begin{array}{l}0 \\
0\end{array}$ & $\begin{array}{l}100 \\
100\end{array}$ & $\begin{array}{l}\text { Cytoplas } \\
\mathrm{m}\end{array}$ \\
\hline Rp112ab & mmR67 & $\begin{array}{l}\text { K.IQNRQAAASVVPSASSLVITALK } \\
\text { EPPR.D }\end{array}$ & $\begin{array}{l}0 \\
0\end{array}$ & $\begin{array}{l}100 \\
100\end{array}$ & $\begin{array}{l}\text { Cytoplas } \\
\mathrm{m}\end{array}$ \\
\hline
\end{tabular}




\begin{tabular}{|l|l|l|l|l|l|}
\hline \multicolumn{2}{|l|}{ Novel Mitochondrial Ribosomal Methylation Sites Found } \\
\hline Protein & Site $^{\boldsymbol{a}}$ & Sequence $^{\boldsymbol{b}}$ & $\begin{array}{l}\text { Percolator } \\
\text { q-value }\end{array}$ & $\begin{array}{l}\text { Methyl Site } \\
\text { Probability }\end{array}$ & $\begin{array}{l}\text { Localizat } \\
\text { ion }\end{array}$ \\
\hline & & $\begin{array}{l}\text { K.IQNRQAAASVVPSASSLVITALK } \\
\text { EPPRD.K }\end{array}$ & & & \\
\hline eEF1A & mmK30 & K.STTTGHLIYKCGGIDKR.T & 0 & 50 & $\begin{array}{l}\text { Cytoplas } \\
\text { m }\end{array}$ \\
\hline $\begin{array}{l}\text { Histone } \\
\text { H3 }\end{array}$ & dmK37 & K.SAPSTGGVKKPHR.Y & 0 & 99.64 & Nucleus \\
\hline
\end{tabular}

${ }^{a}$ Methylated residues are abbreviated as follows: mm- monomethyl, dm- dimethyl, tm- trimethyl.

$b$ Methylated residue is bolded and underlined. Based on residue level probabilities, also underlined are other potentially methylated residues.

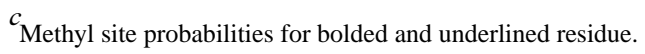

${ }^{d}$ Localization determined from Saccharomyces Genome Database ${ }^{80}$. 
Table 3

Methylated peptides found in the mitochondrial fraction

\begin{tabular}{|c|c|c|c|c|c|}
\hline \multicolumn{6}{|c|}{ Novel Mitochondrial Methylation Sites Found } \\
\hline Protein & Site $^{a}$ & Sequence $^{b}$ & $\begin{array}{l}\text { Percolator } \\
\text { q-value }\end{array}$ & $\begin{array}{l}\text { Methyl Site } \\
\text { Probability }^{c}\end{array}$ & $\begin{array}{l}\text { Localizat } \\
\text { ion }^{d}\end{array}$ \\
\hline Pdb1 & mmR55 & $\begin{array}{l}\text { R.EALNSAMAEELDRDDDVFLIGE } \\
\text { EVAQYNGAYK.V }\end{array}$ & 0 & 0.2 & $\begin{array}{l}\text { Mitochon } \\
\text { dria }\end{array}$ \\
\hline Ald5 & $\operatorname{tmK} 308$ & K.AVㅌNIAFGIFYNSGEVCCAGSR.I & 0 & 100 & $\begin{array}{l}\text { Mitochon } \\
\text { dria }\end{array}$ \\
\hline $\mathrm{Ssa} / 4$ & $\begin{array}{l}\mathrm{mmK} 421 \\
/ 422\end{array}$ & $\begin{array}{l}\text { K.KSEVFSTYADNQPGVLIQVFEGE } \\
\text { R.T }\end{array}$ & 0 & 0.37 & $\begin{array}{l}\text { Cytoplas } \\
\text { m, } \\
\text { Mitochon } \\
\text { dria, } \\
\text { Nucleus, } \\
\text { Vacuole }\end{array}$ \\
\hline Hsp60 & tmK490 & $\begin{array}{l}\text { K.QIIENAGEEGSVIIGKLIDEYGDD } \\
\text { FAK.G }\end{array}$ & 0 & 100 & $\begin{array}{l}\text { Mitochon } \\
\text { dria }\end{array}$ \\
\hline Ald4 & $\operatorname{tmK} 345$ & $\begin{array}{l}\text { R.VYVEESIYDKFIEEFKAASESIK. } \\
\text { V }\end{array}$ & 0 & 33.33 & $\begin{array}{l}\text { Mitochon } \\
\text { dria }\end{array}$ \\
\hline Aco1 & $\operatorname{dmK} 360$ & $\begin{array}{l}\text { K.DLLSADKDAEYDEVVEIDLNTL } \\
\text { EPYINGPFTPDLATPVSK.M }\end{array}$ & - & - & $\begin{array}{l}\text { Mitochon } \\
\text { dria }\end{array}$ \\
\hline \multicolumn{6}{|c|}{ Known Methylation Sites Found } \\
\hline Protein & Site & Sequence & $\begin{array}{l}\text { Percolator } \\
\text { q-value }\end{array}$ & $\begin{array}{l}\text { Methyl Site } \\
\text { Probability }\end{array}$ & $\begin{array}{l}\text { Localizat } \\
\text { ion }\end{array}$ \\
\hline Rp142ab & mmK55 & K.QSGFGGQTKKPVFHK.K & 0 & 100 & $\begin{array}{l}\text { Cytoplas } \\
\mathrm{m}\end{array}$ \\
\hline eEF1A & $\mathrm{mmK} 30$ & $\begin{array}{l}\text { K.STTTGHLIYK.C } \\
\text { K.STTTGHLIY } \underline{\mathbf{K}} \text { CGGIDK.R }\end{array}$ & $\begin{array}{l}0 \\
0\end{array}$ & $\begin{array}{l}100 \\
100\end{array}$ & $\begin{array}{l}\text { Cytoplas } \\
\mathrm{m}\end{array}$ \\
\hline eEF1A & $\operatorname{tmK} 79$ & R.GITIDIALW $\underline{\text { KFETPK.Y }}$ & 0 & 100 & $\begin{array}{l}\text { Cytoplas } \\
\mathrm{m}\end{array}$ \\
\hline
\end{tabular}

${ }^{a}$ Methylated residues are abbreviated as follows: mm- monomethyl, dm- dimethyl, tm- trimethyl.

$b$ Methylated residue is bolded and underlined. Based on residue level probabilities, also underlined are other potentially methylated residues.

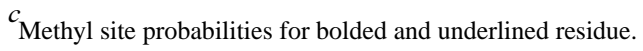

${ }^{d}$ Localization determined from Saccharomyces Genome Database 80 . 